\title{
Cloud Condensation Nuclei properties of model and atmospheric HULIS
}

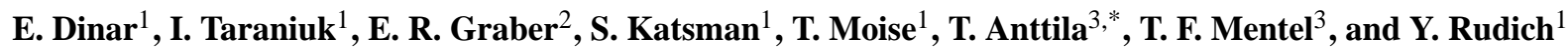 \\ ${ }^{1}$ Department of Environmental Sciences, Weizmann Institute of Science, Rehovot 76100, Israel \\ ${ }^{2}$ Institute of Soil, Water and Environmental Sciences, The Volcani Center, A.R.O., Bet Dagan 50250, Israel \\ ${ }^{3}$ Institute for Tropospheric Chemistry, Research Center Jülich, Jülich Germany \\ *current address: Research and Development, Finnish Meteorological Institute, 00101 Helsinki, Finland
}

Received: 22 December 2005 - Published in Atmos. Chem. Phys. Discuss.: 7 February 2006

Revised: 20 April 2006 - Accepted: 2 May 2006 - Published: 29 June 2006

\begin{abstract}
Humic like substances (HULIS) have been identified as a major fraction of the organic component of atmospheric aerosols. These large multifunctional compounds of both primary and secondary sources are surface active and water soluble. Hence, it is expected that they could affect activation of organic aerosols into cloud droplets. We have compared the activation of aerosols containing atmospheric HULIS extracted from fresh, aged and pollution particles to activation of size fractionated fulvic acid from an aquatic source (Suwannee River Fulvic Acid), and correlated it to the estimated molecular weight and measured surface tension. A correlation was found between $\mathrm{CCN}$-activation diameter of SRFA fractions and number average molecular weight of the fraction. The lower molecular weight fractions activated at lower critical diameters, which is explained by the greater number of solute species in the droplet with decreasing molecular weight. The three aerosol-extracted HULIS samples activated at lower diameters than any of the sizefractionated or bulk SRFA. The Köhler model was found to account for activation diameters, provided that accurate physico-chemical parameters are known.
\end{abstract}

\section{Introduction}

Atmospheric aerosol play important roles in numerous atmospheric processes such as cloud formation, modification of cloud properties, heterogeneous chemistry, and visibility degradation, all of which affect climate forcing and air quality (IPPC, 2001; Andreae et al., 2005; Hansen et al., 2005; Kaufman et al., 2005; Koren et al., 2005; Lohmann and Feichter, 2005). Understanding and predicting aerosol

Correspondence to: Y. Rudich

(yinon.rudich@weizmann.ac.il) particles' climatic effects requires knowledge of their hygroscopic properties at sub and super saturation (SS) conditions. Since only a few inorganic salts constitute the major part of the inorganic aerosol fraction, their hygroscopic behavior has been widely investigated and has been incorporated in modeling studies of simplified pure salts or aerosols composed of two or more inorganic salts species (Heintzenberg, 1989; Clegg et al., 1998; Ansari and Pandis, 1999; Brechtel and Kreidenweis, 2000; Martin et al., 2003; Schlenker et al., 2004; Kreidenweis et al., 2005; Topping et al., 2005). Recent field measurements however, indicate that the mass fraction of organic compounds in fine atmospheric aerosols ranges from $\sim 20$ to $90 \mathrm{wt} \%$, depending on the location and source (Saxena and Hildemann, 1996; Jacobson et al., 2000; Roberts et al., 2001; Putaud et al., 2004; Kanakidou et al., 2005). Laboratory and modeling studies emphasize the importance of this organic fraction for particle properties, and hence their role in various atmospheric processes (Shulman et al., 1996; Laaksonen et al., 1998; Cooke et al., 1999; Lohmann et al., 2000; Chung and Seinfeld, 2002; Rudich, 2003; McFiggans et al., 2005; Mircea et al., 2005). The effects of the organic fraction on aerosol-water vapor interactions depend mainly on three parameters: 1) number of moles in solution, 2) extent of dissociation in aqueous solution, and 3) effect on surface tension.

Several studies have focused on the effect of organic aerosol on cloud droplet nucleation (where aerosol particles act as cloud condensation nuclei (CCN)) and on particles' hygroscopic growth (Facchini et al., 1999; Brooks et al., 2004; Gysel et al., 2004; Ervens et al., 2005). A recent modeling study by Ervens et al. (2005) showed that surface-active compounds with molecular weight higher than 200 AMU have the greatest potential to increase the cloud number concentration (more so at low updraft velocities), and hence the

Published by Copernicus GmbH on behalf of the European Geosciences Union. 
greatest potential to alter cloud properties. CCN activation studies of hydrophilic or hydrophobic multiple component organic-inorganic mixtures (including mixed and coated particles) have resulted in both positive and negative effects on activation depending on the specific system investigated (Cruz and Pandis, 1998; Raymond and Pandis, 2003; Shantz et al., 2003; Bilde and Svenningsson, 2004; Abbatt et al., 2005).

The organic component of atmospheric aerosols is composed of hundreds to thousands of individual species (Saxena and Hildemann, 1996), each contributing only a small mass fraction towards the overall organic matter. Due to its importance in $\mathrm{CCN}$ activation, the organic fraction in atmospheric aerosols is frequently classified on the basis of water solubility, with the water soluble organic carbon (WSOC) fraction making up the major portion of atmospheric organic matter (Saxena and Hildemann, 1996; Facchini et al., 1999; Zappoli et al., 1999).

More then 4 decades ago, Went (1960) suggested that photochemical oxidation of primary volatile and semivolatile organic compounds can produce secondary polymers of high carbon content that may be involved in cloud droplet and haze particle formation. Recent studies of rural and urban particles (Hildemann et al., 1996; Havers et al., 1998; Decesari et al., 2001; Samburova et al., 2005), fogwater (Facchini et al., 2000; Krivacsy et al., 2000; Herckes et al., 2002; Cappiello et al., 2003), marine particulate samples (Tervahattu et al., 2002), and biomass burning aerosols (Hoffer et al., 2004, 2005 ) concluded that 20 to $70 \mathrm{wt} \%$ of the WSOC fraction consists of high molecular weight (HMW) polycarboxylic acids (Graber and Rudich, 2005). These compounds, consisting of a heterogeneous mixture of structures containing aromatic, phenolic and acidic functional groups (Decesari et al., 2001; Krivacsy et al., 2001; Varga et al., 2001; Kiss et al., 2002; Mayol-Bracero et al., 2002; Diallo et al., 2003; Gysel et al. 2004), have certain similarities to humic substances (HS) from terrestrial and aquatic sources. Therefore, these aerosol-associated compounds are referred to in the atmospheric chemistry literature as HUmic-LIke Substances (HULIS). Accumulating evidence shows that HULIS may form in atmospheric particulate matter via photooxidation of primary biogenic and anthropogenic precursors, or may be directly emitted from soils, vegetation, biomass burning and soot automotive exhaust (Gao et al., 2004a, b; Hoffer et al., 2004; Kalberer et al., 2004; Samburova et al., 2005).

Organic compounds in atmospheric aerosol particles alter the physical properties of aerosols substantially compared to particles of pure inorganic salts, mostly by reducing water uptake, and by retaining water to lower relative humidities (RH). These effects often result from their limited solubility and possible effects on surface tension, which depends upon their molecular size and structure (Saxena and Hildemann, 1996; Shulman et al., 1996; Facchini et al., 2000). Many studies have focused on the effects of well defined, small pure organic compounds on $\mathrm{CCN}$ activation (Cruz and Pan- dis, 1997; Corrigan and Novakov, 1999; Giebl et al., 2002; Raymond and Pandis, 2002; Kumar et al., 2003; Raymond and Pandis, 2003; Bilde and Svenningsson, 2004; Abbatt et al., 2005; Abdul-Razzak and Ghan, 2005; Hartz et al., 2005; VanReken et al., 2005). Some have also studied these properties for well defined mass/molar ratio mixtures of pure organic-inorganic salts particles (Brooks et al., 2002; Choi and Chan, 2002; Prenni et al., 2003; Raymond and Pandis, 2003; Pant et al., 2004; Henning et al., 2005). However, the role of surface tension on cloud droplet growth is still not well quantified, despite major efforts (Shulman et al., 1996; Facchini et al., 1999; Facchini et al., 2000; Abbatt et al., 2005; Ervens et al., 2005), mainly due to poor chemicalphysical characterization of real organic compounds present in atmospheric aerosols.

Despite their widespread occurrence, studies on the CCN properties of HULIS are scarce. A few laboratory studies focused on the effect of pure humic substances (HS) and/or their combination with inorganic salts upon sub-saturation hygroscopic growth (Chan and Chan, 2003; Brooks et al., 2004; Gysel et al., 2004; Svenningsson et al., 2006). To the best of our knowledge, there has been only one study of $\mathrm{CCN}$ activation of pure and mixed aerosols containing humic and fulvic acids from commercial sources (Svenningsson et al., 2006), however no such study has been performed on aerosols containing pure HULIS obtained from atmospheric samples.

In this study we present a comparison of critical diameters for droplet activation $\left(D_{c}\right)$ under SS conditions of purified and size-fractionated commercial fulvic acid (Suwannee River Fulvic Acid, SRFA) of aquatic origin to those of FAHULIS extracted from collected wood burning smoke and pollution particles. The goal is to relate activation properties under atmospherically-relevant SS conditions to chemical properties (mainly surface tension and molecular weight) of the model HS and airborne HULIS. Finally, we investigate whether the existing modeling framework (using Köhler theory for activation) can account for the experimental observations, and test the sensitivity of the predictions to the various physico-chemical parameters.

\section{Experimental}

\subsection{Aerosol sampling and HULIS extraction}

Aerosol particles $(<10 \mu \mathrm{m}$, PM10) were collected on $20.3 \times 25.4 \mathrm{~cm}$ QM-A Whatman quartz microfiber filters using a High Volume Sampler (flow rate $70 \mathrm{~m}^{3} / \mathrm{h}$ ) on the roof of a four story building in a green open urban location (Weizmann Institute, Rehovot, Israel). The filters were prebaked at $450^{\circ} \mathrm{C}$ in open aluminum foil envelopes, sealed and stored at $-18^{\circ} \mathrm{C}$. Three samples were collected: 1) Fresh smoke particles (called hereafter LBO-night) were sampled throughout the night (26-27 May 2005) of an extensive, 


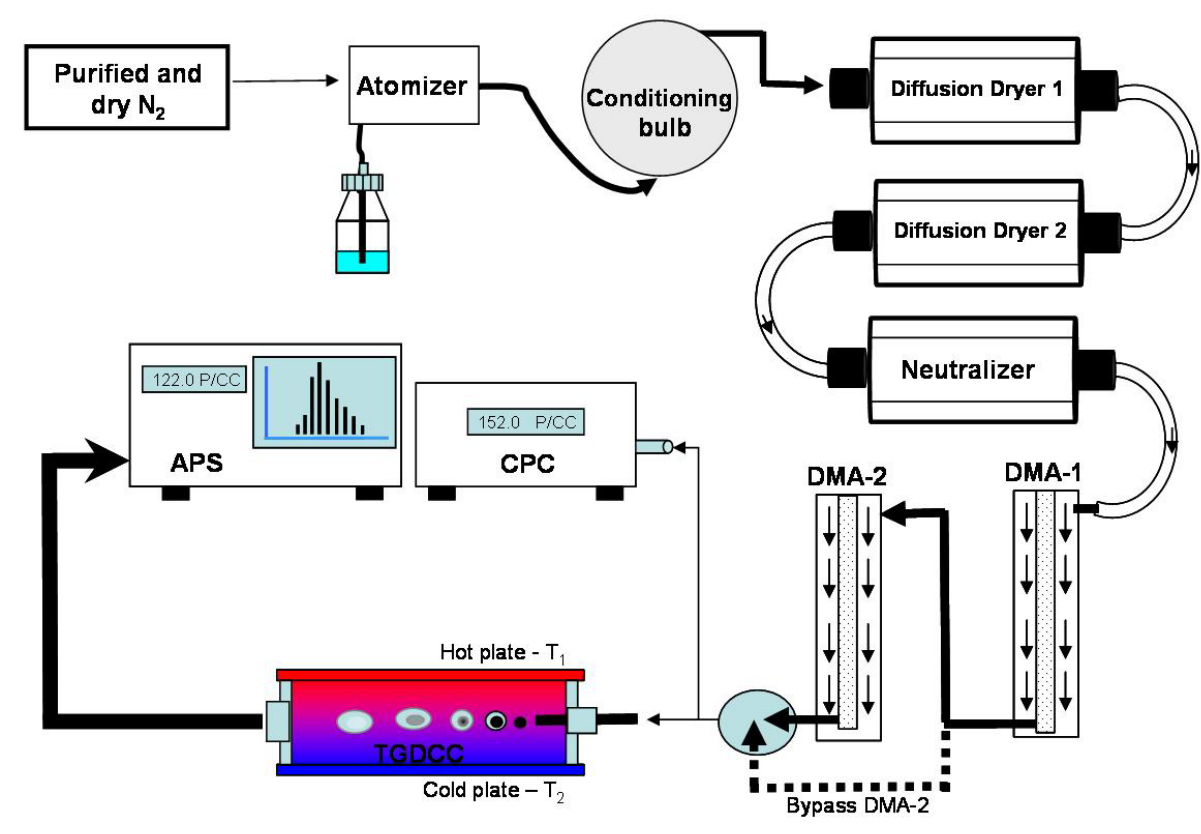

Fig. 1. A schematic presentation of the experimental setup. The dashed line represents the bypass of DMA-2; this pathway is used at low particle concentrations. Between DMA-1 and DMA-2, a diluter apparatus (not shown) was used to control particle number concentration and flow rates.

nation-wide wood burning event, with average PM10 mass concentration near the sampling location of $300-400 \mu \mathrm{g} \mathrm{m}^{-3}$ of smoke, 2) slightly aged wood burning smoke particles (called hereafter LBO-day) were sampled during the morning and early afternoon hours immediately following the nighttime fires (27 May 2005), with PM10 mass concentrations of $60-180\left(\mu \mathrm{g} \mathrm{m}^{-3}\right)$. The LBO-day sample is dominated by smoke particles (as can be concluded from the high aerosol mass concentrations and the dark color of the collected particles), but could have undergone moderate processing via photochemical reactions. 3) The third sample (called 3WSFA) was collected during daytime hours over a three week period (26 July to 16 August 2005), with average PM10 mass concentration of about $25 \mu \mathrm{g} \mathrm{m}^{-3}$. The sample contains the prevailing local photochemical pollution aerosol particles, and is assumed to represent aged particles. The atmospheric conditions during the 3 week period were relatively constant. All mass concentrations were determined by the Israel Ministry of Environment.

HULIS of the fulvic acid type (FA-HULIS) were extracted from the filters and separated from other aerosol components by an isolation procedure developed on the basis of the scheme used by the International Humic Substances Society (IHSS) for separating aquatic humic acid and FA (http: //www.ihss.gatech.edu), and adapted by us for air-borne particulate matter collected on quartz fiber filters. Briefly, filters are subjected to consecutive water and water-base extractions; FA-HULIS, by definition soluble at any $\mathrm{pH}$, were separated from other water soluble and base-soluble aerosol organic and inorganic species by preferential absorption onto an intensively pre-cleaned XAD-8 resin (Supelco Inc.), followed by elution in a basic solution. The eluant was cationexchanged on an $\mathrm{H}^{+}$-saturated cation-exchange resin (AG MP-50, Bio-Rad Laboratories) to produce protonated acids, and then freeze-dried. The freeze-dried samples are stored at room temperature in darkness under vacuum. $18 \mathrm{M} \mathrm{Ohm}$ Mill-Q water was used for all solutions throughout the study.

\subsection{Molecular weight fractionation of Suwannee River Ful- vic Acid}

Suwannee River Fulvic Acid (SRFA, IHSS code 1R101F) of reference grade was obtained from the International $\mathrm{Hu}-$ mics Substances Society (IHSS) and used as a model for atmospheric HULIS. SRFA was chosen because several previous laboratory studies referred to it as representative of atmospheric HULIS (Fuzzi et al., 2001; Haiber et al., 2001; Mircea et al., 2002; Nenes et al., 2002; Chan and Chan, 2003; Abdul-Razzak and Ghan, 2004; Brooks et al., 2004; Rissman et al., 2004; Kiss et al., 2005; Samburova et al., 2005; Svenningsson et al., 2006). The SRFA was de-ashed and cleaned from low molecular weight organic acids and inorganic species by the procedure described above. This was verified by ion chromatography analysis of the samples.

Molecular weight fractionation of SRFA was performed using a diafiltration protocol, providing a coarse subdivision of initially polydisperse material according to an effective size of molecules in solution. The nominal pore sizes of the ultrafiltration membranes do not correspond to the 
actual molecular mass of the fractionated fulvic material, due mainly to molecular conformation and molecule-membrane charge interactions (Schafer et al., 2002), and further analysis is needed for molecular mass determination. The filtration protocol yielded five size fractions of water-soluble material with nominal molecular weight ranges of $0.2-0.5 \mathrm{kDa}, 0.5-$ $1.0 \mathrm{kDa}, 1-3 \mathrm{kDa}, 3-10 \mathrm{kDa}$, and $10-30 \mathrm{kDa}$, denoted F1, F2, F3, F4, and F5, respectively. We estimated the mean molecular weight (MW) of each fraction utilizing correlations available in the literature (see Sect. 2.6). A detailed description of the equipment and procedures used is given in Appendix A.

\subsection{Atomized solutions}

All compounds under investigation were prepared as aqueous solutions: $20-50 \mathrm{mg} / \mathrm{L}$ for ammonium sulfate (AS) and SRFA samples (bulk and fractions), and $10-20 \mathrm{mg} / \mathrm{L}$ for atmospheric HULIS samples. The solutions were atomized using a TSI constant output atomizer (TSI-3076) operating at 20 PSI ( $\sim 2$ Standard Liters per Minute (SLM)) with dry particle-free pure nitrogen, generating a polydisperse distribution of droplets (mean diameter $\sim 0.3 \mu \mathrm{m}$ ).

\subsection{Activation experiments}

A schematic illustration of the experimental setup is shown in Fig. 1. The atomizer flow ( 0.6 SLM) entered a $10 \mathrm{~L}$ conditioning bulb (the rest of the flow was pumped out) resulting in a conditioning time of $\sim 16 \mathrm{~min}$ before entering 3 silica gel column dryers $(R H<3 \%)$. The dry polydisperse aerosol passed through a neutralizer (TSI 3012A) to obtain equilibrium charge distribution on the particles. The polydisperse charged dry particle flow entered a home-built Differential Mobility Analyzer (DMA-1) operating with 6 SLM dry $(R H<3 \%)$ clean sheath flow and fixed at an applied voltage resulting in an output of 0.6 SLM of size selected monodisperse aerosol flow. A second DMA (DMA-2, TSI-3080) was operated either as scanning mobility particle sizer (SMPS, coupled with a condensation particle counter (CPC, TSI3022)) to verify the size distributions, or as an additional size selection step.

The size-selected monodisperse aerosol flow was then directed through a dilution apparatus for precise control of particle number concentration and flow rate. Following dilution, the monodisperse flow was further separated; 0.3 SLM was directed to the CPC for determination of condensation nuclei $(\mathrm{CN})$ number concentration, while the remainder $(0.03-$ 0.2 SLM) entered a home-built Thermal Gradient Diffusion Cloud Chamber (TGDCC) (Kumar et al., 2003).

The TGDCC's top and bottom plates are held at $100 \%$ $R H$ by wet $3 \mathrm{~mm}$ thick Whatman filter papers. By adjusting a temperature gradient between the plates (the average temperature, at the center of TGDCC, was always $26.2^{\circ} \mathrm{C}$ ), effective humidity conditions exceeding $100 \% R H$ were se- lected (Raymond and Pandis, 2002). The SS at the center of the chamber, where the selected particles $(D<350 \mathrm{~nm})$ are injected, can be varied between 0.05 to $2 \%$. The aerosol flow was confined to the center of the TGDCC using a humidified nitrogen flow of $0.8-0.97$ SLM $(R H-100 \%)$, bringing the entire flow (aerosol + sheath) to 1 SLM. The TGDCC is almost identical to that described by Kumar et al. (2003), the only difference being in the number and position of the injector holes. The original design had ten holes of $0.16 \mathrm{~cm}$ in diameter equally spread along the injector tube. We deduced that an injector with 16 holes of the same diameter, concentrated around the center of the tube, results in lower loss of activated particles due to the direct trajectory to the exit. This setup resulted in lower water vapor depletion (the $\mathrm{RH}$ of the entering aerosol flow is $<3 \%$ ) for the same injector distance, and thus higher SS stability. At the exit of the TGDCC, the total flow was directed to an Aerodynamic Particle Sizer (APS, TSI-3321) which counted and sized particles above $0.3 \mu \mathrm{m}$, thus counting only particles that activated to droplets. To reduce droplet loss and evaporation, the APS was placed very close to the chamber's exit, and the RH in the APS was monitored.

The $\mathrm{CN}$ activation efficiency is the ratio between the $\mathrm{CN}$ number concentration entering the TGDCC (determined by the CPC) to the droplet number concentration measured by the APS. By changing the particles' dry size, a plot of the percent of activated particles versus dry diameter is produced. It was previously shown that a sigmoidal fit adequately simulates these experiments and that the critical activation diameter $\left(D_{c}\right)$ for a symmetric distribution of particles, is the diameter where half of the particles activate, or $D_{50}$ (Cruz and Pandis, 1997). In all our experiments, the number density of particles in the TGDCC was between 10 and 100 particles $\mathrm{cm}^{-3}$. Activation experiments for all SRFA samples ( 5 fractions and bulk) and airborne HULIS were carried out at three different SS condition: $0.2,0.52$ and $1.03 \%$. For each SS and sample, the injector position was adjusted to give $100 \%$ activation at large diameters, with the narrowest droplet size distribution. In general, the injector was set further back with decreasing SS setting, to allow a longer residence time (up to $31 \mathrm{~s}$ ) in which particles could be activated. The room temperature was always $3-5^{\circ} \mathrm{C}$ below the average TGDCC temperature.

\subsection{Surface tension measurements}

Surface tension was measured using a Rame-Hart pendant drop tensiometer. Surface tension is derived from image analysis of the drop shape. The time scale of the experiments ranged from a few seconds to a few hours. The advantages of the pendant drop method are that there is minimal contact of the solution with any surface, and that very little material is required ( $1 \mathrm{ml}$ of solution). To increase reproducibility and reliability, the instrument was isolated from vibrations and the droplet was held in a temperature and 
humidity controlled compartment. Surface tension measurements were taken automatically over a preset period of time at a chosen frequency. Mill-Q water was used as a reference sample for all measurements. Three droplets were measured for each concentration.

2.6 UV/VIS spectroscopy for molecular weight and aromaticity estimation

Correlations between absorbance and molecular weight of fulvic acids and aromaticity available in the literature were used for estimating the molecular weight and aromaticity of the SRFA size fractions and HULIS extracted from the collected samples (Chin et al., 1994; Peuravuori and Pihlaja, 1997; Schafer et al., 2002). Sample absorbance was measured with a single-beam UV-VIS Spectrometer (Ultrospec 2100 Pro, Biochrom Ltd.). Sample concentrations ranged from 0.010 to $0.014 \mathrm{gC} / \mathrm{L}$, determined on the basis of elemental analysis. Elemental analysis of dry and ash-free samples was performed with a Carbo Erba EA-1108 Elemental Analyzer.

Absorbance values at $280 \mathrm{~nm}$ and $254 \mathrm{~nm}$ were used for calculating the molar absorptivities $(\varepsilon)$. The wavelength of $280 \mathrm{~nm}$ was chosen by Peuravuori and Pihlaja (1997) and by Chin et al. (1994) because the $\pi-\pi *$ electron transition for most aromatic hydrocarbons, thought to be structural sub-units in humic substances, occurs in the region of 270$280 \mathrm{~nm}$ (Traina et al., 1990). However, $280 \mathrm{~nm}$ is not the peak wavelength, as the UV/VIS spectra of humic matter are broad. As a result, Schafer et al. (2002) worked at $254 \mathrm{~nm}$.

Molar absorptivities at 254 and $280 \mathrm{~nm}$ for SRFA and airborne FA fractions ranged from 156 to $507 \mathrm{Lmol}^{-1} \mathrm{~cm}^{-1}$ of organic carbon and appeared to fall within the range reported by others for isolated humic fractions (Chin et al., 1994; Peuravuori and Pihlaja, 1997; Schafer et al., 2002). Additional details on the derivation of the correlations and the definitions of number-averaged molecular weight $\left(M_{N}\right)$ and weight-averaged molecular weight $\left(M_{W}\right)$ are given in Appendix B.

\subsection{Determination of acidity content of SRFA}

The amount of carboxylic groups in the bulk SRFA and in the fractionated samples was determined by potentiometric titrations of aqueous solutions with $\mathrm{KOH}$ using a Metler Toledo Automatic Titration instrument. Sample solutions in $0.05 \mathrm{M} \mathrm{KCL}$ (used to maintain a constant ionic strength) were stored under nitrogen. During titration to $\mathrm{pH} 10.0$ in a nitrogen atmosphere, solutions were continuously de-aerated to eliminate dissolution of carbon dioxide and oxygen. The equivalence point of the carboxylic groups was set at $\mathrm{pH} 8.0$ (Swift, 1996).
Table 1. Comparison of ammonium sulfate activation diameters (mean \pm standard deviation of 6-14 experiments, conducted on different days) under different SS conditions with predictions using the classical Köhler equation. The Van't Hoff factor was calculated using a concentration-dependent parameterization by Young and Warren (1992).

\begin{tabular}{cll}
\hline SS (\%) & $\begin{array}{l}\text { Measured activation } \\
\text { dry diameter }(\mathrm{nm})\end{array}$ & $\begin{array}{l}\text { Predicted Activation } \\
\text { dry diameter }(\mathrm{nm})\end{array}$ \\
\hline 0.2 & $79.8 \pm 6.9$ & 82.4 \\
0.4 & $53.9 \pm 2.3$ & 52.6 \\
0.52 & $46.4 \pm 1.1$ & 44.4 \\
0.80 & $34.5 \pm 1.5$ & 33.7 \\
1.03 & $31.3 \pm 0.4$ & 28.8 \\
\hline
\end{tabular}

\section{Results}

\subsection{System validation}

Ammonium sulfate (AS) was used for validating the system's performance since its CCN activation at different SS conditions is well known (Tang et al., 1995; Cruz and Pandis, 1997; Corrigan and Novakov, 1999; Brechtel and Kreidenweis, 2000; Raymond and Pandis, 2002; Kumar et al., 2003; Kreidenweis et al., 2005). The system was validated using AS at five different SS conditions: 0.2, 0.4, 0.52, 0.8 and $1.03 \%$. The obtained activation curves are presented in Fig. 2. A summary and comparison between our experimental results for activation diameters $\left(D_{50}\right)$ of AS to calculated activation diameters using the Köhler equation are given in Table 1. It is concluded that our measured $D_{50}$ for all tested SS conditions are in good agreement with predicted and measured diameters.

While some studies with TGDCC employed large normalization factors $(\sim 1.4)$ to correct for $100 \%$ activation (Cruz and Pandis, 1997; Corrigan and Novakov, 1999; Brechtel and Kreidenweis, 2000; Kumar et al., 2003), our system does not require such high normalization factors. The normalization factor applied in all of our experiments did not exceed 1.06 in the lower limit and 0.98 in the upper limit. This correction results from loss of large droplets in the TGDCC (in the lower limit) and deviation error between the CPC and the APS (mostly in the upper limit).

While the system is reliable and steady, there is a deviation from the sigmoidal fit at $10-30 \%$ activation in the low SS experiments (see Fig. 2 experimental curves of 0.2 and $0.4 \% \mathrm{SS}$ ). We attribute the activation bias at low SS and at small particle sizes to the non-ideal monodisperse size distribution produced by the DMA, as also invoked by $\mathrm{Ku}-$ mar et al. (2003). This conclusion is further supported by the observation of a slight broadening of the distribution towards larger particle sizes in the monodisperse size spectra, which leads to faster activation of the "leaked" large particles 
Table 2. Molecular weight and aromaticity estimates for the different samples. $M_{W}$ and $M_{N}$ were estimated based on correlations given by Schafer et al. (2002). Aromaticity estimates are based upon correlation results of Peuravuori and Pihlaja (1997). The absorbativity at 254 and $280 \mathrm{~nm}$ as well as the surface tension of $1 \mathrm{gr} / \mathrm{L}$ solutions at $90 \mathrm{~min}$ are also given (mean \pm standard deviation).

\begin{tabular}{|c|c|c|c|c|c|c|}
\hline Sample & $M_{w}$ & $M_{n}$ & $\begin{array}{c}\varepsilon \text { at } 254 \mathrm{~nm} \\
\mathrm{~L} \mathrm{~mole}^{-1} \mathrm{~cm}^{-1}\end{array}$ & $\begin{array}{c}\varepsilon \text { at } 280 \mathrm{~nm} \\
\mathrm{~L} \mathrm{~mole}^{-1} \mathrm{~cm}^{-1}\end{array}$ & Aromaticity (\%) & $\begin{array}{c}S T_{90}(\text { dyne } / \mathrm{cm}) \\
\text { at } 90 \mathrm{~min}\end{array}$ \\
\hline F1 & 450 & 440 & 241 & 156 & 12 & $57.1 \pm 0.9$ \\
\hline $\mathrm{F} 2$ & 650 & 520 & 344 & 236 & 16 & $62.8 \pm 0.3$ \\
\hline F3 & 910 & 620 & 482 & 347 & 23 & $59.5 \pm 0.4$ \\
\hline F4 & 1150 & 720 & 611 & 466 & 30 & $62.1 \pm 0.4$ \\
\hline F5 & 1210 & 740 & 639 & 507 & 32 & $59.5 \pm 1.2$ \\
\hline SRFA bulk & 780 & 570 & 416 & 306 & 20 & $59.0 \pm 0.7$ \\
\hline LBO-night & 1200 & 610 & 206 & 320 & 20 & $45.4 \pm 3.3$ \\
\hline LBO-day & 560 & 410 & 462 & 121 & 10 & $43.9 \pm 1.6$ \\
\hline 3WSFA & 610 & 500 & 322 & 227 & 16 & $55.5 \pm 0.4$ \\
\hline
\end{tabular}

Table 3. Elemental composition of the SRFA fractions. Due to the small quantities, the elemental composition of extracted FA-HULIS could not be measured.

\begin{tabular}{cccccccc}
\hline Sample & $\begin{array}{c}\mathrm{N} \\
\%\end{array}$ & $\begin{array}{c}\mathrm{C} \\
\%\end{array}$ & $\begin{array}{c}\mathrm{H} \\
\%\end{array}$ & $\begin{array}{c}\mathrm{S} \\
\%\end{array}$ & $\begin{array}{c}\mathrm{O} \\
\%\end{array}$ & $\begin{array}{c}\mathrm{O} / \mathrm{C} \\
\text { mole/mole }\end{array}$ & $\begin{array}{c}\mathrm{H} / \mathrm{C} \\
\text { mole/mole }\end{array}$ \\
\hline F1 & 0.54 & 54.78 & 5.24 & $\mathrm{n} / \mathrm{a}$ & 39.44 & 0.54 & 1.15 \\
F2 & 0.63 & 50.86 & 4.71 & 0.44 & 43.37 & 0.64 & 1.11 \\
F3 & 0.67 & 50.63 & 4.33 & 0.31 & 44.07 & 0.65 & 1.03 \\
F4 & 0.77 & 52.17 & 4.56 & 0.31 & 42.20 & 0.61 & 1.05 \\
F5 & 0.73 & 49.71 & 4.01 & 0.40 & 45.16 & 0.68 & 0.97 \\
SRFA bulk & 0.68 & 53.36 & 4.88 & 0.26 & 40.82 & 0.57 & 1.10 \\
\hline
\end{tabular}

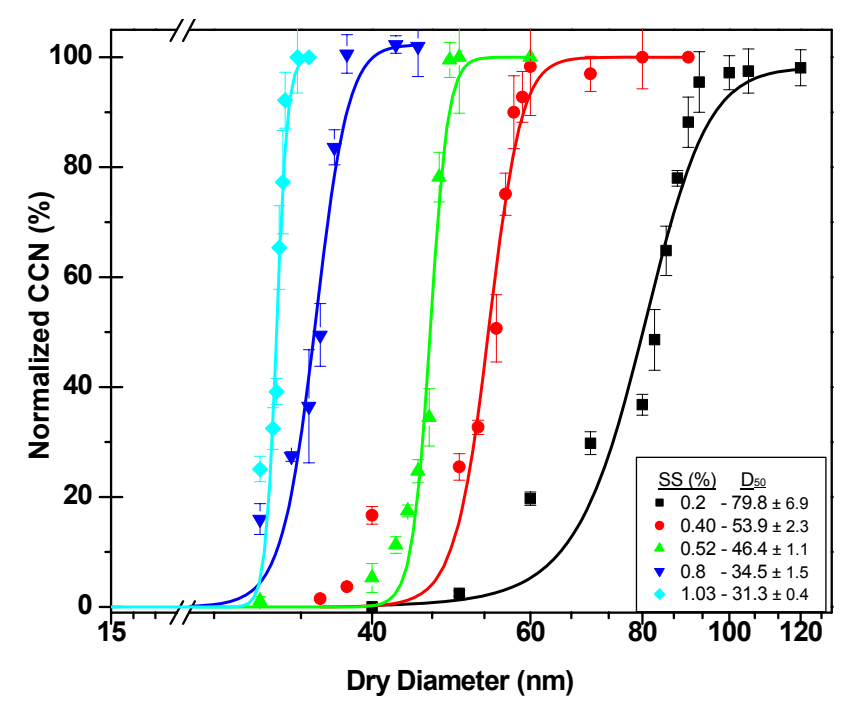

Fig. 2. Activation curves of ammonium sulfate particles. The activation diameter $\left(D_{50}\right)$ is indicated in the legend for all SS measured. The error bars represent the standard deviation for each point of 614 experiments, conducted on different days. compared to the majority of the size-selected particles. It is expected that this effect will be more severe at low SS conditions, where activation is lower. This effect was diminished when two size selection steps were used. A tandem sizeselection setup was used when a sufficient number of particles remained after the first size selection.

\subsection{Molecular weight, aromaticity and elemental composi- tion}

The SRFA samples and aerosol-derived FA average molecular weight and aromaticity (as percent of total weight carbon) were estimated using the correlations available in the literature for UV/VIS spectroscopy for aquatic and terrestrial fulvic and humic acids. It should be kept in mind that such correlations have not been used previously for atmospheric HULIS. The results of UV/VIS absorption spectroscopy of the size fractionated samples are given in Table 2. The resulting average $M_{N}$ of the SRFA fractions, estimated by the correlation provided by Schafer et al. (2002) ranged from $450 \mathrm{AMU}$ to $740 \mathrm{AMU}$, with the bulk SRFA giving $570 \mathrm{AMU}$. The average $M_{N}$ of the FA-HULIS aerosol extracts are 610, 410 and 500 AMU for the LBO-night, LBO- 
day and 3WSFA samples, respectively. The number and average molecular size estimates based on UV spectroscopy of the extracted HULIS are larger than previous estimates of the molecular sizes of atmospheric HULIS (Kiss et al., 2003).

A correlation between the nominal molecular weight cutoffs of the membranes used for SRFA fractionation with the estimated $M_{N}$ and $M_{W}$ was observed. Likewise, aromaticity was seen to increase with increasing molecular weight, and with it, the brown color of the sample. The bulk SRFA had a color similar to that of F4.

The results of the elemental analysis are shown in Table 3. In general, the oxygen to carbon molar ratio is above 0.5 , with increasing $\mathrm{O} / \mathrm{C}$ ratio as molecular weight increases. The obtained elemental content is consistent with values provided for bulk SRFA (www.ihss.gatech.edu). The H/C ratio decreases with molecular weight, which is consistent with the higher aromaticity estimated from the UV absorbance. Due to the small amounts of extracted HULIS, we were not able to conduct this analysis for the aerosol extracts.

\subsection{Surface tension}

Surface tension of $1 \mathrm{~g} / \mathrm{L}$ aqueous solutions of the size fractionated SRFA samples and the HULIS extracts after $90 \mathrm{~min}$ $\left(S T_{90}\right)$ are reported in Table 2. We treat 90 min values as equilibrium surface tension, although our time dependent measurements (not published) suggest that even at this long time, some solutions do not reach equilibrium with respect to surface tension. The most surface active of the SRFA fractions is F1 (lowest average $M_{N}$ of $440 \mathrm{AMU}$ ), with a $S T_{90}$ of $57 \mathrm{dyne} / \mathrm{cm} . S T_{90}$ of the other fractions varies from a high of 63 for F2 (average $M_{N}$ of $520 \mathrm{AMU}$ ), to 60 for both F3 and F5 (average $M_{N}$ of 620 and $740 \mathrm{AMU}$, respectively). There was no clear relationship between $S T_{90}$ and $M_{N}$. The HULIS samples were substantially more surface active at the same $1 \mathrm{~g} / \mathrm{L}$ concentration than even the smallest of the SRFA fractions, with $S T_{90}$ values for HULIS extracted from fresh and aged smoke particles of 45 and 44 dyne/cm (LBO-night and LBO-day, respectively), and 56 dyne/cm for the 3 week photochemical pollution samples (3WSFA). Greater surface activity for HULIS as compared with aquatic fulvic acids has been previously reported by Kiss et al. (2005) and Facchini et al. (2000).

\subsection{SRFA acidity}

The results of the titrations of SRFA are given in Table 4 . It is concluded that the acidity content per carbon generally decreases with increase of molecular weight with the exception of the lowest average $M_{N}$ fraction (F1). From the titration curves we conclude that SRFA is a weak acid, and at atmospherically relevant concentrations (Facchini et al., 2000), dissociation in aqueous solution will be low. The average number of carboxylic groups per molecule in each fraction can be estimated to range between $\sim 2$ for F1 to $\sim 3$
Table 4. Acidity content of SRFA samples.

\begin{tabular}{ccc}
\hline Sample & \multicolumn{2}{c}{ Titration until $\mathrm{pH}=8$} \\
$\mathrm{mmol} / \mathrm{g}$ & $\mathrm{mmol} / \mathrm{gOC}$ \\
\hline F1 & 4.4 & 8.0 \\
F2 & 5.6 & 11.0 \\
F3 & 5.0 & 9.9 \\
F4 & 4.4 & 8.4 \\
F5 & 3.8 & 7.6 \\
SRFA bulk & 5.1 & 9.6 \\
\hline
\end{tabular}

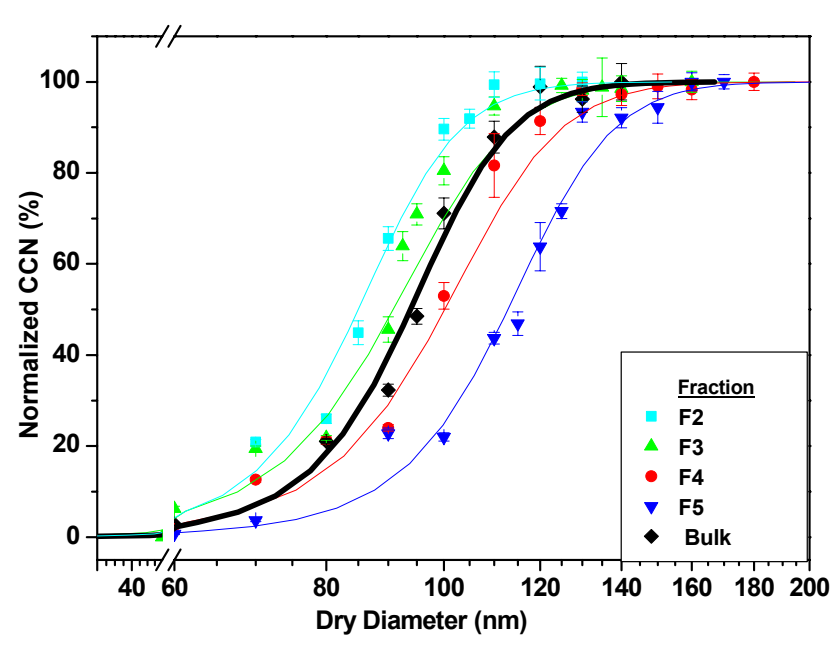

Fig. 3. An example for activation curves for all SRFA fractions at $\mathrm{SS}=0.52 \%$. The bulk sample (black line) lies between the $1-3 \mathrm{kDa}$ to the $3-10 \mathrm{kDa}$. This behavior is repeatable in all SS measured for these samples. A clear correlation between the mass and activation diameter exists. The error bars represent the standard deviation for each point of 6-14 experiments, conducted on different days.

for F5, and $\sim 2.7$ carboxylic groups per molecule for the bulk SRFA. These values are in the range obtained also by Ritchie and Perdue (2003) for SRFA and Tagliavini et al. (2006) for HULIS extracted from smoke particles in Brazil. Due to scarce amount of extracted and purified material, we were not able to repeat the acidity measurements and elemental analysis measurements for the aerosol extracts.

\subsection{CCN activity of size-fractionated SRFA}

Table 5 shows the activation diameters of the SRFA fractions at three different super saturation conditions. Figure 3 presents the results of activation experiments carried out on SRFA fractions and bulk at a SS of $0.52 \%$. Activation curves are qualitatively similar to those of AS, and can be fit with a sigmoidal growth curve. It can be seen that the lower molecular weight fractions activate more efficiently than higher molecular weight fractions (i.e.; F1 compared with F5), and that the activation diameter increases as 
Table 5. Summary of all measured activation diameters for fractionated, bulk SRFA samples and HULIS samples. The error bars represent the standard deviation for an average of 3-5 experiments.

\begin{tabular}{ccccccc}
\hline Sample & $\begin{array}{c}\text { Activation diameter }(\mathrm{nm}) \\
\text { SS-0.2\% }\end{array}$ & $R^{2}$ & $\begin{array}{c}\text { Activation diameter }(\mathrm{nm}) \\
\text { SS-0.52\% }\end{array}$ & $R^{2}$ & \multicolumn{2}{c}{$\begin{array}{c}\text { Activation diameter }(\mathrm{nm}) \\
\text { SS-1.02\% }\end{array}$} \\
\hline F1 & $\mathbf{1 6 4 . 7} \pm 14.8$ & 0.971 & $\mathbf{8 6 . 9} \pm .5$ & 0.987 & $\mathbf{5 8 . 3} \pm 3.1$ & 0.995 \\
F2 & $\mathbf{1 6 4 . 0} \pm 14.3$ & 0.986 & $\mathbf{8 5 . 8} \pm 7.5$ & 0.990 & $\mathbf{5 4 . 9} \pm 3.7$ & 0.993 \\
F3 & $\mathbf{1 6 8 . 6} \pm 10.6$ & 0.986 & $\mathbf{9 4 . 6} \pm 5.0$ & 0.985 & $\mathbf{5 4 . 1} \pm 5.6$ & 0.985 \\
F4 & $\mathbf{1 9 1 . 6} \pm 12.1$ & 0.995 & $\mathbf{9 7 . 8} \pm 9.9$ & 0.990 & $\mathbf{6 3 . 1} \pm 3.2$ & 0.982 \\
F5 & $\mathbf{2 1 2 . 2} \pm 11.8$ & 0.994 & $\mathbf{1 1 8 . 3} \pm 5.8$ & 0.982 & $\mathbf{6 9 . 0} \pm 4.6$ & 0.990 \\
SRFA Bulk & $\mathbf{1 8 0 . 7} \pm 13.4$ & 0.991 & $\mathbf{9 5 . 5} \pm 5.5$ & 0.964 & $\mathbf{5 8 . 2} \pm 4.8$ & 0.997 \\
LBO- Night & $\mathbf{1 3 3 . 8} \pm 11.1$ & 0.999 & $\mathbf{6 9 . 6} \pm 4.7$ & 0.987 & $\mathbf{4 0 . 6} \pm 2.0$ & 0.983 \\
LBO- Day & $\mathbf{9 9 . 4} \pm 7.4$ & 0.995 & $\mathbf{5 5 . 0} \pm 2.5$ & 0.993 & $\mathbf{3 7 . 4} \pm 2.5$ & 0.985 \\
3WSFA & $\mathbf{8 1 . 0} \pm 5.6$ & 0.982 & $\mathbf{4 7 . 6} \pm 4.7$ & 0.989 & $\mathbf{3 5 . 3} \pm 1.4$ & 0.997 \\
\hline
\end{tabular}

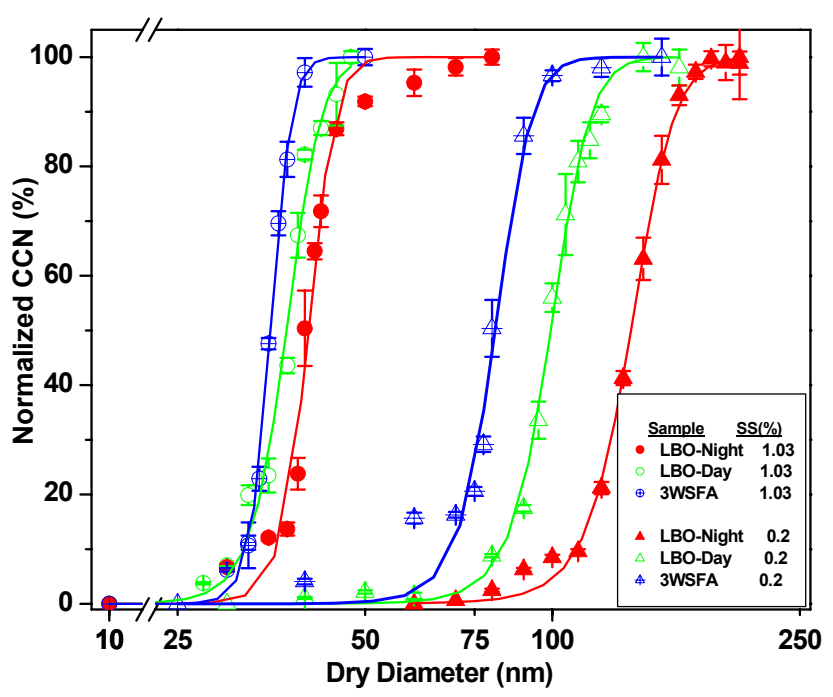

Fig. 4. Activation experiments with extracted FA HULIS under SS conditions of 0.2 and $1.03 \%$. Experiments were carried out by atomizing solution of FA extracted from collected smoke particles. Refer to the text for explanation of the samples. Activation experiments under SS of $0.52 \%$ exhibit same behavior (see Table 5).

$M_{N}$ increases. Activation of bulk SRFA is interim between F3 and F4, consistent with results for estimated molecular weight, and the knowledge that SRFA is dominated by relatively small molecular weight species (Piccolo, 2001; Simpson et al., 2001; Sutton et al., 2005). The same behavior is seen at all supersaturations (see Table 5). Fractions 1 and 2 $\left(M_{N}\right.$ of 440 and $\left.520 \mathrm{AMU}\right)$ exhibit almost identical growth and critical activation diameters under the same conditions. Considering that aromaticity is inversely related to molecular weight, it can be stated that as aromaticity increases, activation decreases. The aromaticity trend is also consistent with the sample visible color (discussed above). The emergent general pattern relating activation efficiency to chemical na- ture is that the browner the fraction, the higher the molecular weight and aromaticity, and the poorer the activation.

\subsection{Activation of aerosol-extracted FA-HULIS}

Activation experiments were carried out for the three aerosol extracts under the same SS conditions as for SRFA samples $(0.2,0.52$ and $1.03 \%)$. Due to the small dry mass of samples obtained for each of these samples $(<6 \mathrm{mg})$, no size fractionation was possible for these samples. It was verified by ion chromatography (Falkovich et al., 2004; Falkovich et al., 2005) that the samples did not contain low molecular weight organic acids. Activation diameters, obtained from a sigmoidal fit to the activation curves, are tabulated in Table 5. Figure 4 shows the activation curves of the three samples at SS of $0.2 \%$ and $1.03 \%$. It can be seen that the daytime smoke sample (LBO-day) is more CCN-active than the extracts of the fresh nighttime smoke particles (LBO-night). This may suggest possible photochemical processing during day time, mainly by OH-radicals, ozone and possibly UV which leads to enhanced degradation of FA and a decrease of its average molecular weight (Table 2). It is also conceivable that this sample contains some of the prevailing pollution particles. However, given the daily PM loadings at the site, and the dark color of the collected particles, it is unlikely that there was a major contribution of pollution particles to the collected smoke particles. This behavior is also supported by the $M_{N}$ estimated for these samples: 610 AMU for the fresh smoke sample, and 410 AMU for the slightly aged sample, and by the lower aromaticity of the daytime sample. The observed lower aromaticity may imply some processing by ozone and $\mathrm{OH}$ radicals. The day-time pollution particles sample (3WSFA) was significantly more $\mathrm{CCN}$-active than the extracts from both of the smoke samples. However, the estimated molecular weight (500 AMU) and aromaticity $(15 \%)$ are higher than the day smoke sample. This may suggest that the HULIS formed in the photochemical pollution particles are different than those in the smoke particles and 
direct comparison between them is not straightforward. It may also be that the correlations used to estimate the molecular weight and the aromaticity, based as they are on terrestrial and aquatic FA, are not appropriate for HULIS. Activation experiments for these HULIS samples at SS of $0.52 \%$ were also performed, resulting with the same pattern (see Table 5).

\section{Discussion}

4.1 Activation of model compounds in comparison to authentic HULIS

We have attempted to learn how the activation of aerosolderived HULIS and model aquatic FA depends on their molecular weight, chemical properties and surface activity. There is a clear positive correlation between activation diameter of SRFA fractions and number average molecular weight $\left(M_{N}\right)$ of the fraction. Because fulvic acids do not dissociate significantly in dilute aqueous solution at the estimated droplet concentrations (1-2 mmol/L; Kiss et al., 2005), this activation trend can be explained by the simple fact that the lower the molecular weight, the greater the number of solute species in the droplet.

The three aerosol-extracted FA-HULIS samples activate at a lower diameter than any of the size-fractionated or bulk SRFA. At $1.03 \%$ SS, there is a $20 \mathrm{~nm}$ difference in the activation diameter between the most active SRFA and the most $\mathrm{CCN}$-active extract (Table 5). At SS more relevant to ambient SS, there is an even larger difference in activation properties between the aerosol HULIS samples and the most CCNactive fraction (F1). For example, at $\mathrm{SS}=0.2 \%$, SRFA fractions $1-3\left(M_{N}=440,520\right.$ and $\left.600 \mathrm{AMU}\right)$ activate at between 170 and $160 \mathrm{~nm}$, while aerosol HULIS extracts $\left(M_{N}=410\right.$, 500 , and $610 \mathrm{AMU}$ ) activate at 80,100 , and $135 \mathrm{~nm}$, respectively. The difference in the activation efficiencies of the extracts may be attributed to lower molecular weight estimated by the UV correlations.

\subsection{Modeling of activation based on the Köhler theory}

The aim of the modeling efforts was to test if $\mathrm{CCN}$ activity of HULIS could be predicted from by the Köhler equation using measured physical-chemical properties and whether surface tension reduction affects activation. The following form of the Köhler equation was applied (Seinfeld and Pandis, 1998; Kreidenweis et al., 2005):

$$
\begin{aligned}
& \ln \left(S_{\mathrm{wat}}\right)=\frac{A}{D_{p}}-\frac{B}{D_{p}^{3}}, \\
& A=\frac{4 M W_{w} \sigma_{\mathrm{sol}}}{R T \rho_{w}}, \\
& B=\frac{6 i n_{s} M W_{w}}{\pi \rho_{w}} .
\end{aligned}
$$

Here $S_{\text {wat }}$ is the saturation ratio of water over a droplet having a diameter $D_{p}, M W_{w}$ is the molecular weight of water, $\sigma_{\text {sol }}$ is the droplet surface tension, $R$ is the universal gas constant,
$T$ is the temperature, $\rho_{w}$ is the water density, $i$ is the van't Hoff factor which accounts for a non-ideal behavior of the solution (Pruppacher and Klett, 1980), and $n_{s}$ is the number of solute molecules in the droplet. The last quantity can be written as $n_{s}=m_{s} / M W_{s}$, where $m_{s}$ and $M W_{s}$ are the solute dry mass and its molecular weight, respectively. It should be noted that various individual compounds dissolved in the droplets are treated here as a single solute, and that partition of the compounds to the surface is not treated explicitly. It is also implicitly assumed here that the compounds are infinitely soluble, based on previous experiments which showed that fulvic acid is highly water soluble. Hence, in the current experiments, we believe that the SRFA particles activate to droplets with no solid core. So far, probably due to the difficulty in sampling and extracting sufficient experimental material, water solubility of HULIS has not been tested to our knowledge.

Given that the values of the required parameters are known, Eq. (1) can be differentiated to obtain the number of solute molecules needed for droplet activation at a certain water saturation ratio $S$ (Seinfeld and Pandis, 1998). Substituting the saturation ratios applied in the $\mathrm{CCN}$ measurements for $S$ and converting the resulting numbers of moles to particle size, we obtain the so-called dry activation diameters which can be compared with the measured activation diameters $D_{50}$ (given in Table 5). The choice of the required parameters is discussed in the following.

The titration results show that the investigated FAs are weak acids, hence are not expected to dissociate significantly in aqueous solution at atmospherically-relevant concentrations. We neglect also other deviations from a non-ideal behavior. Accordingly, the value of $i$ in Eq. (1) is set equal to unity, or was varied to check the sensitivity of activation to possible dissociation. To investigate whether FAs are sufficiently surface-active to influence $\mathrm{CCN}$ activation, calculations were performed using two different values for the solution phase surface tension: that of water and that measured at the concentration of $1 \mathrm{~g} / \mathrm{L}$ after $90 \mathrm{~min}$ of equilibration. This concentration is within the range of HULIS concentrations calculated for a droplet after activation (Kiss et al., 2005). Particle dry density $\rho_{\text {dry }}$ is set equal to $1.5 \mathrm{~g} \mathrm{~cm}^{-3}$ (De Wit et al., 1993). The choice of the remaining parameter, $M W_{s}$, is discussed in the next paragraph.

Individual compounds comprising a FA sample can be described with a continuous distribution and thus the total number of molecules in a sample, $n_{\text {tot }}$, and its mass, $m_{\text {tot }}$, are obtained by integrating over the size distribution:

$$
\begin{aligned}
n_{\mathrm{tot}} & =\int_{M W^{-}}^{M W^{+}} n(M W) d M W, \\
m_{\mathrm{tot}} & =\int_{M W^{-}}^{M W^{+}} n(M W) M W d M W,
\end{aligned}
$$



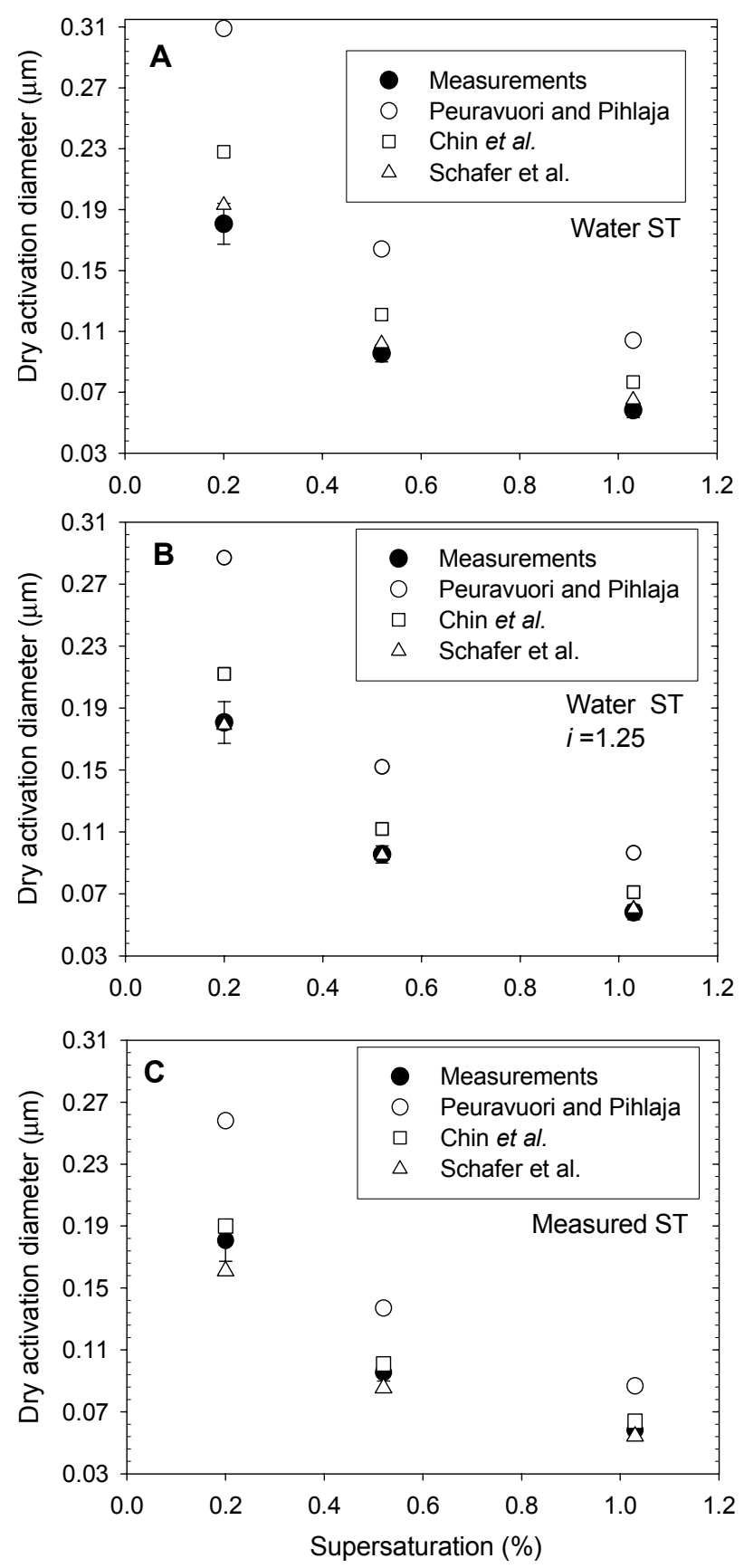

Fig. 5. The measured (solid symbols) and calculated (hollow symbols) dry diameters needed for particle activation for the bulk SRFA sample. The correlation used in estimating $M_{n}$ is displayed in the legend. The particle surface tension is assumed to be either that of water (a and b) or taken from the measurements (c). The Van't Hoff factor is set equal to unity (a and c) or to 1.25 (b).

where $n(M W)$ is the distribution function and $\left(M W^{-}\right.$, $\left.M W^{+}\right)$is the molecule size range in the sample. In the Köhler equation given by Eq. (1), all individual species in the sample are described by a single compound. Therefore
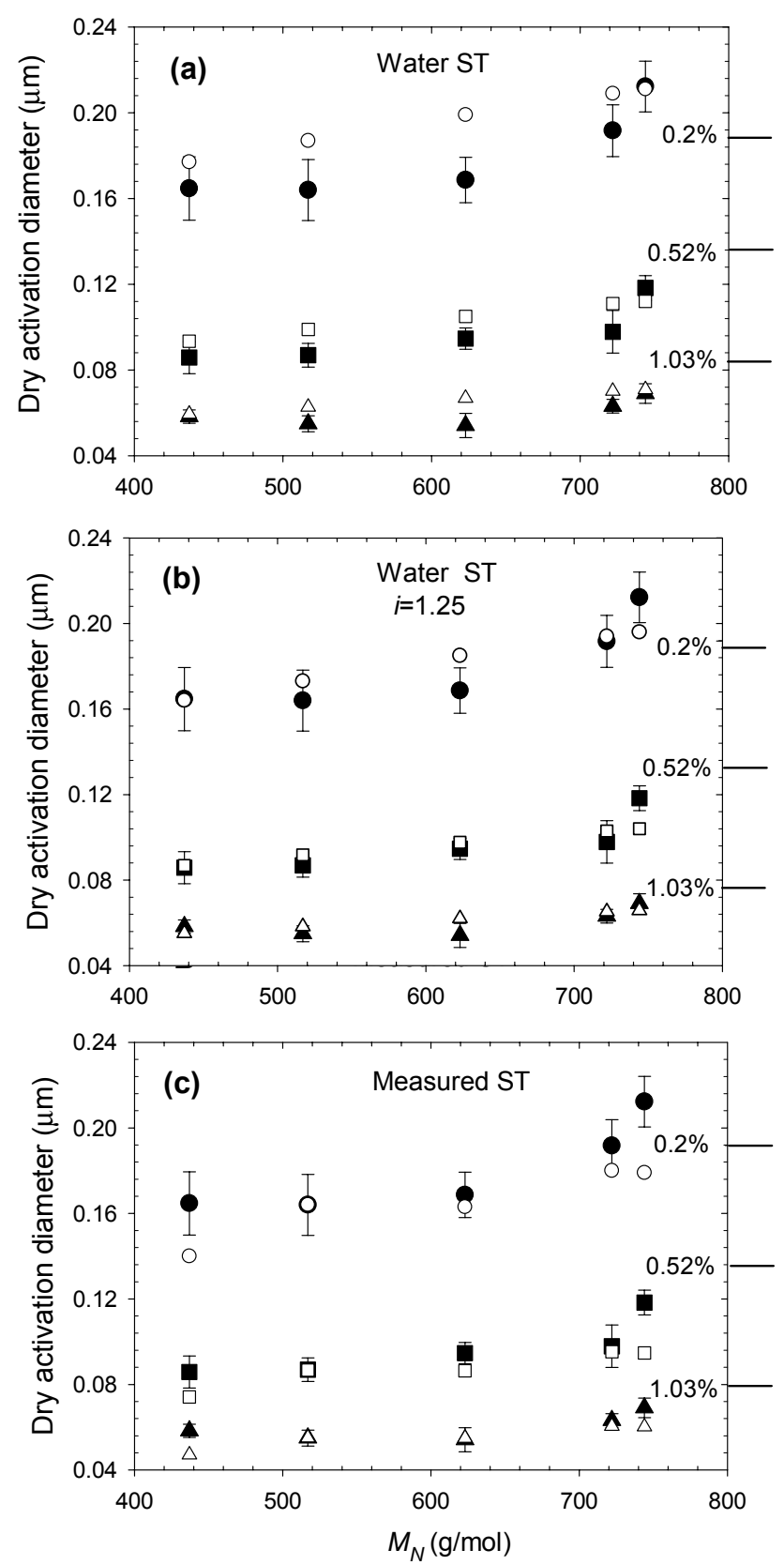

Fig. 6. The measured (solid symbols) and calculated (hollow symbols) dry diameters needed for particle activation for the sizefractionated SRFA samples. Circles, squares and triangles indicate the activation diameters at supersaturations $0.2,0.52$ and $1.03 \%$, respectively. The correlation of Schafer et al. (2002) is used in estimating $M_{n}$. The particle surface tension is assumed to be either that of water (a and b) or taken from the measurements (c). The Van't Hoff factor is set equal to unity (a and c) or to 1.25 (b).

$M W_{s}$ is an "effective" mole weight which relates the number of molecules present in the sample with the sample total mass, i.e. $n_{\text {tot }}=m_{\text {tot }} / M W_{s}$. Combining this equation with 
Eq. (2) yields:

$$
M W_{s}=\frac{\int_{M W^{-}}^{M W^{+}} n(M W) M W d M W}{\int_{M W^{-}}^{M W^{+}} n(M W) d M W}
$$

Using the correlations (Chin et al., 1994; Peuravuori and Pihlaja, 1997; Schafer et al., 2002), it is possible to estimate the molecular weight, as described above. This is done by relating the UV peak absorbance, $h$, to the mass. Assuming that the proportionality constant does not depend significantly on the molecular size, we obtain the following equation for $M W_{s}$ :

$$
M W_{s} \approx \frac{\int_{M W^{-}}^{M W^{+}} h(M W) d M W}{\int_{M W^{-}}^{M W^{+}}(h(M W) / M W) d M W}=M W_{n},
$$

where $h(M W)$ is the absorbance of species having a molar weight $M W$ and $M_{N}$ is the number-averaged molecular weight. Equation (4) shows that $M_{N}$ serves as a proxy for $M W_{s}$ in Eq. (1) when droplets contain a number of individual weakly or non-dissociating compounds.

\subsubsection{Model calculations versus measurements}

The dry activation diameters $\left(D_{\text {calc }}\right)$ were calculated using the above-described approach and compared with the experimentally determined activation diameters $D_{50}$. Results are shown separately for the bulk- and size-fractionated samples in Figs. 5-6, respectively. Several correlations between absorbance and $M_{N}$ were employed in this study to estimate the number-averaged molecular weights for both the bulk and size-fractionated samples (see Sect. 3.2). In order to find the one most consistent with $\mathrm{CCN}$ measurements, the Köhler calculations were initially repeated using the molecular weight estimates from each of the correlations. Figure 5a shows the calculated activation diameter for the bulk sample using the three different UV absorbance-molecular weight correlations and assuming no dissociation of the acids (i.e. the van't Hoff factor ( $i$ ) is unity), and a surface tension of water. It can be seen that the calculations over-predict the activation diameter by $10-100 \%$, and that the correlation that most closely reproduces the observed activation diameters for the bulk sample is that of Schafer et al. (2002), with that of Chin et al. (1994) being about 20\%-30\% less accurate. The correlation of Peuravuori and Pihalja (1997) yields significantly larger dry activation diameters, i.e. the molecular weight estimates for the bulk samples and the size-fractions are too high to be commensurable with the $\mathrm{CCN}$ measurements. The discrepancies increase with the increasing molecular weight and supersaturation. This behavior is repeated in all calculations, hence we conclude that the molecular weight estimates from the correlation of Schafer et al. (2002) are most suitable for our samples.

In Fig. 5b, the calculations are repeated, using the same correlations for molecular weight estimates, and again setting the surface tension to that of water. In these calculations, however, it is also assumed that some dissociation of the FA occurs. Hence, $i$ was varied to reach best agreement between the estimation based on the Schafer et al. (2002) correlation and the observations. It was found that $i=1.25 \mathrm{re}-$ produces a good agreement with the observations. This van't Hoff factor is consistent with the $20 \%$ dissociation which can be estimated from the titrations performed. In Fig. 5c, $i$ was set to unity, and the surface tension as set to the values measured in the laboratory. This figure shows that the measured lower surface tensions can account for the overestimation of the activation diameter presented in Fig. 5a.

In Fig. 6, the same calculations are repeated for the different SRFA fractions, and for the three different supersaturations. In general, one can again conclude that setting the van't Hoff factor to 1.25, or setting surface tension equal to measured values can better explain the observed activation diameters. Comparison of $D_{50}$ for the fraction with average $M_{N}$ of $620 \mathrm{AMU}$ and those for bulk samples shows that the latter size range is the closest to the bulk sample in terms of the $\mathrm{CCN}$ activation, in agreement with the activation measurements.

With the behavior observed for the SRFA bulk and the fractions, it is possible to conclude that the surface tension does not play a major role in the activation of SRFA samples and that the activation is dominated by the concentration and the slight dissociation of the SRFA. It should be noted that the surface tensions measured at equilibrium might be substantially different compared with the instantaneous surface tension close to activation. This is due to possible higher concentrations and to kinetic effects observed in the surface tension measurements which, considering the short timescale of the CCN activation may have prevented the droplets from reaching an equilibrium surface tension value during activation. The HULIS concentrations in the droplets at the onset of activation may exceed that of $1 \mathrm{~g} / \mathrm{L}$ used for equilibrium surface tension measurements.

We performed an additional sensitivity study investigating the effect of the particle dry density $\rho_{\text {dry }}$ to the $\mathrm{CCN}$ activity predictions. The calculations (not illustrated by a figure) showed that changing $\rho_{\text {dry }}$ from 1.5 to $1.0 \mathrm{~g} \mathrm{~cm}^{-3}$ increases $D_{\text {calc }}$ by approximately $10 \%$ and consequently, $\rho_{\text {dry }}$ is of a secondary importance compared to $M_{N}$ and $\sigma_{\text {sol }}$.

To summarize, the SRFA calculation results show that the CCN activation behavior of SRFA particles can be successfully predicted using the traditional Köhler theory provided that the relevant physico-chemical properties are well characterized, especially surface activity, degree of dissociation, and statistical properties of the molecular weight distribution. However, we cannot uniquely determine the relative 

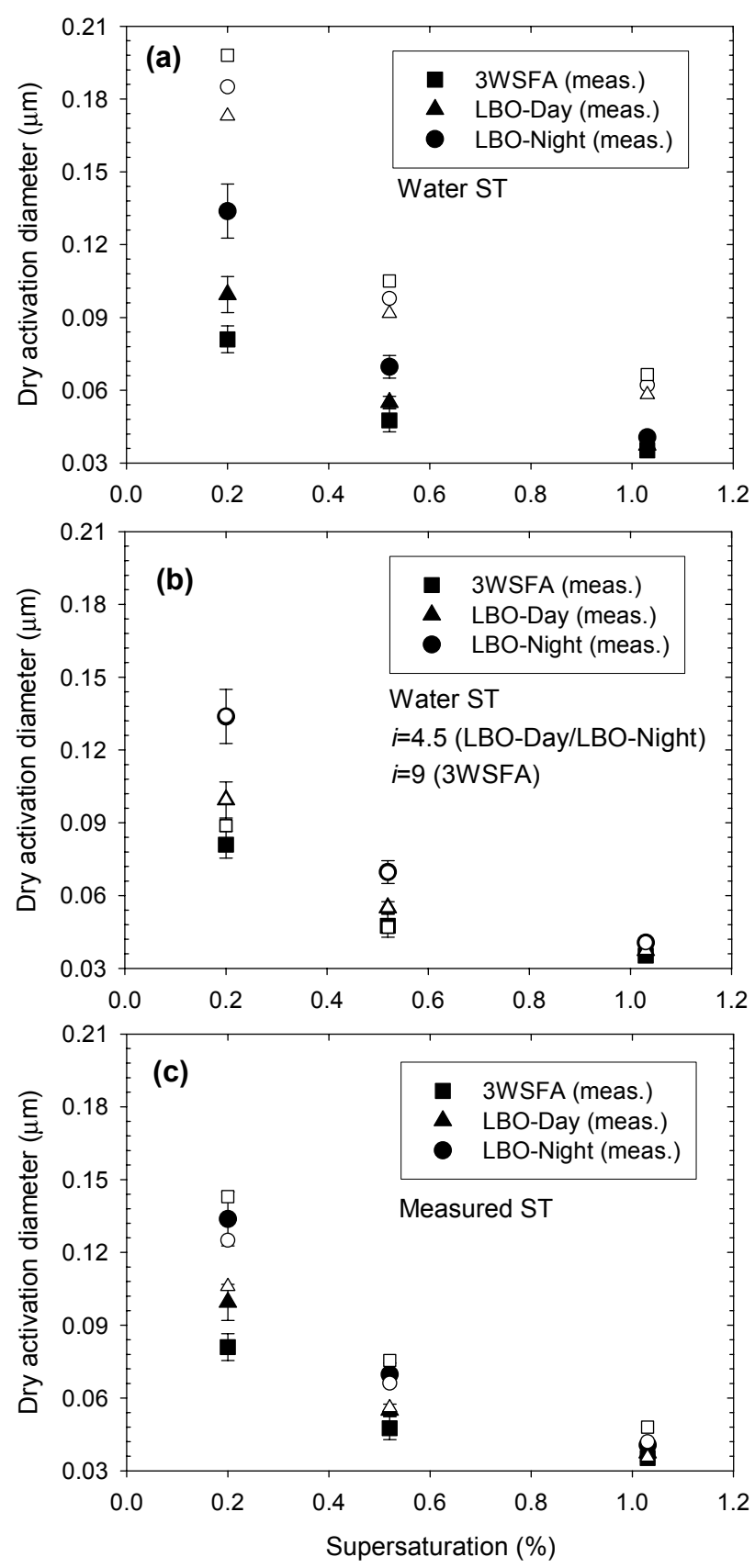

Fig. 7. The measured (solid symbols) and calculated (hollow symbols) dry diameters needed for particle activation for the extracted FA HULIS samples. The correlation of Schafer et al. (2002) is used in estimating $M_{n}$. The particle surface tension is assumed to be either that of water (a and b) or taken from the measurements (c). The Van't Hoff factor is set equal to unity (a and c) or varied (b). It is found that $i=4.5$ can account for the LBO samples, and $i=9$ can account for the behavior of the 3WSFA sample.

contribution of dissociation versus surface tension in the case of SRFA activation.
4.2.2 Köhler calculations for FA extracted from aerosol particles

Figures 7a, b and $\mathrm{c}$ show the results of $\mathrm{CCN}$ activation calculations based on the Köhler theory together with variations in van't Hoff factor and with surface tension measurements for the sample extracts. The same approach is applied as for the SRFA samples. The calculations are performed for number molecular weights $\left(M_{N}\right)$ assuming that the correlations of Schafer et al. (2002) hold also for the atmospheric FA. In Fig. $7 \mathrm{a}$, surface tension of water and $i=1$ were assumed. In Fig. 7b, the van't Hoff factor was varied to obtain the best agreement between the predicted and measured activation diameters, while surface tension was set to that of water. For the FA extracts from smoke samples (LBO-night and LBOday) best agreement was achieved with a van't Hoff factor equal to 4.5 and for the pollution-derived FA (3WSFA), a van't Hoff factor of 9 had to be assumed in order to achieve a good agreement between calculated measured activation diameters. In Fig. 7c, a van't Hoff factor of 1, and the measured surface tension values were used. It can seen that using the measured surface tension values, activation diameters can be very well predicted, even if $i=1$ is assumed. Considering that HULIS molecules may consist of 3 or more carboxylic groups per molecule (Tagliavini et al., 2006), then a van't Hoff factor of 4.5 could be reasonable if the HULIS was fully dissociated. Unfortunately, we did not have enough material to determine an acid titration curve for the HULIS extracts, and therefore cannot estimate either $\mathrm{pK}_{\mathrm{a}}$ or degree of dissociation for atmospherically relevant concentrations. However, it is extremely unlikely that a van't Hoff factor could be as high as 9. Therefore, at least for the 3WSFA sample (and to smaller extant the LBO samples), surface tension may play an important role, or possibly, our molecular weight estimates are inadequate.

A dry density of $1.5 \mathrm{~g} / \mathrm{cm}^{-3}$ was assumed in all calculations. Changing the dry density to $1.0 \mathrm{~g} \mathrm{~cm}^{-3}$ increases the predicted activation diameters by $13 \%$, resulting in a worse fit to the data (analysis not shown).

\subsection{Atmospheric implications}

To our knowledge, this is the first study on the CCN activity of HULIS extracted from sampled particles. We can, however, compare the CCN activity of the bulk SRFA measured here with those obtained by Svenningsson et al. (2006), who measured the activation diameters of bulk SRFA. The activation experiments carried out by Svenningsson et al. (2006) were conducted by selecting a particular aerosol size and scanning super saturation conditions in the CCN spectrometer. As a result, their experiments can not be directly compared with this work. However, for atmospherically relevant SS conditions of $0.2 \%$ and $0.5 \%$, the activation diameters of bulk SRFA (180 and $90 \mathrm{~nm}$, respectively) obtained in both studies agree very well. 
While we have found that the fractions of SRFA with the lower molecular size activate to droplets at smaller diameters than the bulk SRFA, water soluble FA-HULIS extracted from fresh and slightly aged smoke particles and from air pollution particles activate to cloud droplets more effectively than even the SRFA fraction with the lowest molecular weight. For these water soluble organic molecules, activation can be reasonably well predicted by the Köhler model, provided that the molecular weight, the amount of dissociation and the surface tension can be estimated. The calculations suggest that surface tension is more important than dissociation for the activation of the extracted HULIS (assuming the inferred molecular weight estimates). It can also be concluded from Fig. 7c, that the 3WSFA sample behaves differently than the smoke samples, and as a result the calculation of its activation diameters gives the worst result, compared to that of the LBO-Night and LBO-Day samples.

The activation of the airborne HULIS is qualitatively similar to that of fulvic acid from an aquatic source often used as a model system in laboratory studies, i.e.; Suwannee River fulvic acid. However, we found that HULIS derived from 3 different aerosol sources (fresh smoke, aged smoke, and photochemical pollution) are more $\mathrm{CCN}$ active, more surface active than SRFA and generally less aromatic. The measured activation diameters also suggest that chemical aging of these organic species may improve their $\mathrm{CCN}$ abilities due to oxidation of larger molecular species to smaller ones (compare LBO-day with LBO-night). It is still unclear whether the FAHULIS from smoke aerosols can be directly compared with those from pollution particles, such that more samples and studies of this sort are needed. It is also clear that standard isolation and chemical characterization methods of HULIS must be adopted for enabling future interpretation and comparison of results from different studies.

The surface tension measurements reported here examined only one concentration, representative of the concentrations of HULIS found in atmospheric samples of fog and rainwater. Surface activity controlled by large HULIS molecules will be a function of concentration and of time in a growing droplet. Hence it is conceivable that at the onset of activation, the concentrations of HULIS may actually be higher than those studied here. Yet, for the SRFA fractions, the calculations above using the Köhler equation (Sect. 4.2) demonstrate that there is no need to invoke surface activity to account or the observed activation. Therefore, concentration and time dependent surface tension were not considered for these samples. For the HULIS samples, where surface tension does appear to play a role in activation, the extracted amounts were unfortunately too small for us to test the concentration dependence.

By size-fractionating the SRFA sample and measuring the surface tension of the samples, we demonstrated that the activation of SRFA to droplets depends on the physico-chemical parameters (molecular weight, surface tension) of these complex organic species, but we were not always able to show this to the same extent for the aerosol-derived HULIS, as there was not enough material for detailed chemical analysis. However, it seems plausible to conclude from the results shown here that surface tension does not play an important role in activation of SRFA, but plays a certain role in promoting activation of the aerosol-derived FA. Finally, the differences in CCN activation behavior between even the smallest FA fractions and HULIS extracted from aerosol suggest that the materials are not as similar as previously believed.

A major knowledge gap that still remains open concerns the physical-chemical and hygroscopic properties of nonwater soluble species. Synergetic hygroscopic effects with salts such as ammonium sulfate also need to be studied to assess the role of these species in real atmospheric aerosol particles.

\section{Appendix A Materials and equipment for fractionation procedure}

Membranes: YM series Millipore membranes from regenerated cellulose of nominal molecular weight cutoffs (NMWCO) of $0.5,1,3,10$ and $30 \mathrm{kDa}$ were used. A membrane of $200 \mathrm{Da}$ nominal molecular weight cutoff obtained from $\mathrm{KOCH}$ membrane systems was also employed $\mathrm{KOCH}$ : MPF-34). Prior to use, the membranes were flushed by $800 \mathrm{ml}$ of water to remove preservative. When not in use, they were stored in $20 \%$ ethanol.

Filtration Equipment: The set up consists of a feed cell (volume of $800 \mathrm{~mL}$ ) and magnetically stirred filtration cell (Amicon, volume of $180 \mathrm{~mL}$, membrane diameter $63 \mathrm{~mm}$ ) pressurized with nitrogen to $3 \mathrm{~kg} \mathrm{~cm}^{-2}$. Filtration was carried out at $23 \pm 2^{\circ} \mathrm{C}$.

Filtration Protocol: Sequential filtration beginning with the largest NMWCO membrane $(30 \mathrm{kDa})$ and continuing to the smallest $(0.2 \mathrm{kDa})$ was carried out. A diafitration protocol (constant cell volume) was employed to avoid excessive aggregation in solution during the course of filtration. A $150 \mathrm{~mL}$ bulk solution at $5 \mathrm{~g} / \mathrm{L}$ was placed in the filtration cell and the feed cell filled with water and pressurized. During each filtration stage, more than tenfold volume $(1800 \mathrm{~mL})$ of water passed the filtration cell, washing it from species which could pass through the membrane. The filtrate was collected and concentrated to $150 \mathrm{~mL}$ in the filtration cell on the membrane with the next (smaller) NMWCO, followed by washing with $1800 \mathrm{~mL}$ water. The retentate was freeze-dried and stored in the dark under vacuum. The filtrate with species of NMW <200 Da was discharged. Obtained fractions were periodically tested by ion chromatography to assure absence of low molecular weight organic acids and inorganic ions. 


\section{Appendix B}

Chin et al. (1994) reported a molar absorptivity $(\varepsilon)$ of $389 \mathrm{Lmol}^{-1} \mathrm{~cm}^{-1}$ of OC for bulk SRFA at $280 \mathrm{~nm}$. We measured an absorptivity of $306 \mathrm{Lmol}^{-1} \mathrm{~cm}^{-1}$ of OC at $280 \mathrm{~nm}$, which, considering batch diversity and differences in instrumentation, is not substantially different from the previous result.

Additionally, Chin et al. (1994) correlated absorbance at $280 \mathrm{~nm}$ for a variety of different humic and fulvic acids with aromaticity (measured as \% of carbon in aromatic structures) determined by ${ }^{13} \mathrm{C}$ NMR spectroscopy, and number-averaged molecular weight $\left(\mathrm{M}_{N}\right)$ determined by size exclusion chromatography (SEC) and vapor-pressure osmometry. The relationship between aromaticity and absorbance obtained was:

$\left.\operatorname{Aromaticity}(\%)=0.05 \times \varepsilon+6.74, \quad R^{2}=0.90\right)$

A later study correlating absorbance at $280 \mathrm{~nm}$ with aromaticity determined by ${ }^{13} \mathrm{C}$ NMR for various humic samples and size fractionated humic samples, reported a similar equation (Peuravuori and Pihlaja, 1997):

Aromaticity $(\%)=0.057 \times \varepsilon+3.001, \quad R^{2}=0.84$

The maximum difference between the estimations does not exceed $30 \%$ for HS where absorptivities range between 100 and $500 \mathrm{Lmol}^{-1} \mathrm{~cm}^{-1}$ of OC.

A good correlation $\left(R^{2}=0.97\right)$ between weight-averaged molecular weight and molar absorptivity at $280 \mathrm{~nm}$ was found by Chin et al. (1994). They did not develop an equation for number-averaged molecular weight $\left(M_{N}\right)$, and we used their data (Table 1, p. 1856) for regression analysis. The resulting relationship is not as good $\left(R^{2}=0.83\right)$ as that for weight-averaged molecular weight $\left(M_{W}\right)$ but is a useful, semi-predictive tool:

$M_{N}(D a)=1.33 \times \varepsilon+534, \quad R^{2}=0.83$

Peuravuori and Pihlaja (1997) suggested a logarithmic equation:

$\log _{10}\left(M_{N}\right)=0.003 \times \varepsilon+2.452, \quad R^{2}=0.77$

No correlation was proposed by Schafer et al. (2002), but using their published data (five samples), a relationship between molar absorptivity at $254 \mathrm{~nm}$ and $\mathrm{M}_{N}$ (evaluated on the basis of SEC analysis) can be obtained:

$M_{N}=92.1 \times \varepsilon+253, \quad R^{2}=0.72, n=5$

Our absorptivities (ranging from 2.0 to $5.3 \mathrm{~L} \mathrm{mg}^{-1} \mathrm{~m}^{-1}$ of OC) are partially outside the narrow range of data (3.05$3.99 \mathrm{~L} \mathrm{mg}^{-1} \mathrm{~m}^{-1}$ of OC) in the study of Schafer et al. (2002).

The number average molecular weight, $M_{N}$, represents the total weight of the molecules present divided by the total number of molecules. Most thermodynamic measurements are based on number-average molecular weight, including the colligative properties such as osmotic pressure and freezing point depression. It is calculated by:

$\overline{M_{N}}=\frac{\sum_{i=0}^{\infty} N_{i} M_{i}}{\sum_{j=0}^{\infty} N_{j}}$

where the number of molecules having a given molecular weight $\left(M_{i}\right)$ is given by $N_{i}$, and $N_{j}$ is the total number of molecules present.

An alternative measure for the molecular weight of a polymer is the weight average molecular weight $\left(M_{W}\right) . M_{W}$ is a weighted average considering the mass of the molecules, so that heavier molecules have relatively more importance than lighter molecules. $M_{W}$ is calculated by:

$\overline{M_{W}}=\frac{\sum_{i=0}^{\infty} N_{i} M_{i}^{2}}{\sum_{j=0}^{\infty} N_{j} M_{j}}$

The ratio of weight average to the number average molecular weight is $M_{W} / M_{N}$ known as the polydispersity, an index of the distribution of molecular weights in the mixture. Knowledge of the molecular weight is essential for activation growth modeling, and we have used the three correlation equations in our modeling studies.

Acknowledgements. This work was supported by a grant from the Israel Academy of Sciences (grant \#162/05). Aerosol ambient concentrations were provided by the Israel Ministry of Environment. T. Anttila acknowledges financial support from the Helsingin Sanomat Centennial Foundation. Valuable help from J. Abbatt in the design of the cloud chamber is highly appreciated.

Edited by: A. Laaksonen

\section{References}

Abbatt, J. P. D., Broekhuizen, K., and Kumal, P. P.: Cloud condensation nucleus activity of internally mixed ammonium sulfate/organic acid aerosol particles, Atmos. Environ., 39(26), 4767-4778, 2005.

Abdul-Razzak, H. and Ghan, S. J.: Parameterization of the influence of organic surfactants on aerosol activation, J. Geophys. Res., 109, D03205, doi:03210.01029/02003JD004043, 2004.

Abdul-Razzak, H. and Ghan, S. J.: Influence of slightly soluble organics on aerosol activation, J. Geophys. Res., 110, D06206, doi:06210.01029/02004JD005324, 2005.

Andreae, M. O., Jones, C. D., and Cox, P. M.: Strong present-day aerosol cooling implies a hot future, Nature, 435(7046), 11871190, 2005.

Ansari, A. S. and Pandis, S. N.: Prediction of multicomponent inorganic atmospheric aerosol behavior, Atmos. Environ., 33(5), 745-757, 1999. 
Bilde, M. and Svenningsson, B.: CCN activation of slightly soluble organics: the importance of small amounts of inorganic salt and particle phase, Tellus Ser. B-Chem. Phys. Meteorol., 56(2), 128134, 2004.

Brechtel, F. J. and Kreidenweis, S. M.: Predicting particle critical supersaturation from hygroscopic growth measurements in the humidified TDMA. Part II: Laboratory and ambient studies, J. Atm. Sci., 57(12), 1872-1887, 2000.

Brooks, S. D., DeMott, P. J., and Kreidenweis, S. M.: Water uptake by particles containing humic materials and mixtures of humic materials with ammonium sulfate, Atmos. Environ., 38(13), 1859-1868, 2004.

Brooks, S. D., Wise, M. E., Cushing, M., and Tolbert, M. A.: Deliquescence behavior of organic/ammonium sulfate aerosol, Geophys. Res. Lett., 29, 1917, doi:1910.1029/2002GL014733, 2002.

Cappiello, A., De Simoni, E., Fiorucci, C., Mangani, F., Palma, P., Trufelli, H., Decesari, S., Facchini, M. C., and Fuzzi, S.: Molecular characterization of the water-soluble organic compounds in fogwater by ESIMS/MS, Environ. Sci. Tech., 37(7), 1229-1240, 2003.

Chan, M. N. and Chan., C. K.: Hygroscopic properties of two model humic-like substances and their mixtures with inorganics of atmospheric importance, Environ. Sci. Tech., 37(22), 5109-5115, 2003.

Chin, Y. P., Aiken, G., and Oloughlin, E.: Molecular-Weight, Polydispersity, And Spectroscopic Properties Of Aquatic Humic Substances, Environ. Sci. Tech., 28(11), 1853-1858, 1994.

Choi, M. Y. and Chan, C. K.: The effects of organic species on the hygroscopic behaviors of inorganic aerosols, Environ. Sci. Tech., 36(11), 2422-2428, 2002.

Chung, S. H. and Seinfeld, J. H.: Global distribution and climate forcing of carbonaceous aerosols, J. Geophys. Res., 107, 4407, doi:4410.1029/2001JD001397, 2002.

Clegg, S. L., Brimblecombe, P., and Wexler, A. S.: Thermodynamic model of the system $\mathrm{H}^{+}-\mathrm{NH}^{4+}-\mathrm{Na}^{+}-\mathrm{SO}_{4}^{2-}-\mathrm{NB}_{3}-\mathrm{Cl}-\mathrm{H}_{2} \mathrm{O}$ at $298.15 \mathrm{~K}, \mathrm{~J}$. Phys. Chem. A, 102(12), 2155-2171, 1998.

Cooke, W. F., Liousse, C., Cachier, H., and Feichter, J.: Construction of a 1 degrees $\mathrm{x} 1$ degrees fossil fuel emission data set for carbonaceous aerosol and implementation and radiative impact in the ECHAM4 model, J. Geophys. Res., 104(D18), 22 137$22162,1999$.

Corrigan, C. E. and Novakov, T.: Cloud condensation nucleus activity of organic compounds: a laboratory study, Atmos. Environ., 33 (17), 2661-2668, 1999.

Cruz, C. N. and Pandis, S. N.: A study of the ability of pure secondary organic aerosol to act as cloud condensation nuclei, Atmos. Environ., 31(15), 2205-2214, 1997.

Cruz, C. N. and Pandis, S. N.: The effect of organic coatings on the cloud condensation nuclei activation of inorganic atmospheric aerosol, J. Geophys. Res., 103(D11), 13 111-13 123, 1998.

De Wit, J. C. M., Vanriemsdijk, W. H., and Koopal, L. K.: Proton Binding To Humic Substances.1. Electrostatic Effects, Environ. Sci. Tech., 27(10), 2005-2014, 1993.

Decesari, S., Facchini, M. C., Matta, E., Lettini, F., Mircea, M., Fuzzi, S., Tagliavini, E., and Putaud, J. P.: Chemical features and seasonal variation of fine aerosol water-soluble organic compounds in the Po Valley, Italy, Atmos. Environ., 35(21), 36913699, 2001.
Diallo, M. S., Simpson, A., Gassman, P., Faulon, J. L., Johnson, J. H., Goddard, W. A., and Hatcher, P. G.: 3-D structural modeling of humic acids through experimental characterization, computer assisted structure elucidation and atomistic simulations. 1. Chelsea soil humic acid, Environ. Sci. Tech., 37(9), 1783-1793, 2003.

Ervens, B., Feingold, G., and Kreidenweis, S. M.: Influence of water-soluble organic carbon on cloud drop number concentration, J. Geophys. Res., 110, D18211, doi:18210.11029/12004JD005634., 2005.

Facchini, M. C., Decesari, S., Mircea, M., Fuzzi, S., and Loglio, G.: Surface tension of atmospheric wet aerosol and cloud/fog droplets in relation to their organic carbon content and chemical composition, Atmos. Environ., 34(28), 4853-4857, 2000.

Facchini, M. C., Fuzzi, S., Zappoli, S., Andracchio, A., Gelencser, A., Kiss, G., Krivacsy, Z., Meszaros, E., Hansson, H. C., Alsberg, T., and Zebuhr, Y.: Partitioning of the organic aerosol component between fog droplets and interstitial air, J. Geophys. Res., 104(D21), 26 821-26 832, 1999.

Facchini, M. C., Mircea, M., Fuzzi, S., and Charlson, R. J.: Cloud albedo enhancement by surface-active organic solutes in growing droplets, Nature, 401(6750), 257-259, 1999.

Falkovich, A. H., Graber, E. R., Schkolnik, G., Rudich, Y., Maenhaut, W., and Artaxo, P.: Low molecular weight organic acids in aerosol particles from Rondonia, Brazil, during the biomassburning, transition and wet periods, Atmos. Chem. Phys., 5, 781797, 2005, http://www.atmos-chem-phys.net/5/781/2005/.

Falkovich, A. H., Schkolnik, G., Ganor, E., and Rudich, Y.: Adsorption of organic compounds pertinent to urban environments onto mineral dust particles, J. Geophys. Res., 109, D02208, doi:02210.01029/02003JD003919, 2004.

Fuzzi, S., Decesari, S., Facchini, M. C., Matta, E., Mircea, M., and Tagliavini, E.: A simplified model of the water soluble organic component of atmospheric aerosols, Geophys. Res. Lett., 28(21), 4079-4082, 2001.

Gao, S., Keywood, M., Ng, N. L., Surratt, J., Varutbangkul, V., Bahreini, R., Flagan, R. C., and Seinfeld, J. H.: Low-molecularweight and oligomeric components in secondary organic aerosol from the ozonolysis of cycloalkenes and alpha-pinene, J. Phys. Chem. A, 108(46), 10 147-10 164, 2004a.

Gao, S., Ng, N. L., Keywood, M., Varutbangkul, V., Bahreini, R., Nenes, A., He, J. W., Yoo, K. Y., Beauchamp, J. L., Hodyss, R. P., Flagan, R. C., and Seinfeld, J. H.: Particle phase acidity and oligomer formation in secondary organic aerosol, Environ. Sci. Tech., 38(24), 6582-6589, 2004b.

Giebl, H., Berner, A., Reischl, G., Puxbaum, H., Kasper-Giebl, A., and Hitzenberger, R.: CCN activation of oxalic and malonic acid test aerosols with the University of Vienna cloud condensation nuclei counter, J. Aerosol Sci., 33(12), 1623-1634, 2002b.

Graber, E. R. and Rudich, Y.: Atmospheric HULIS: How HumicLike Are They? A Comprehensive and Critical Review, Atmos. Chem. Phys., 6, 729-753, 2006, http://www.atmos-chemphys.net/6/729/2006/.

Gysel, M., Weingartner, E., Nyeki, S., Paulsen, D., Baltensperger, U., Galambos, I., and Kiss, G.: Hygroscopic properties of water-soluble matter and humic-like organics in atmospheric fine aerosol, Atmos. Chem. Phys., 4, 35-50, 2004, http://www.atmos-chem-phys.net/4/35/2004/.

Haiber, S., Herzog, H., Burba, P., Gosciniak, B., and Lambert, J.: 
Two-dimensional NMR studies of size fractionated Suwannee River Fulvic and Humic Acid Reference, Environ. Sci. Tech., 35(21), 4289-4294, 2001.

Hansen, J., Sato, M., Ruedy, R., et al.: Efficacy of climate forcings, J. Geophys. Res., 110, D18104, doi:18110.11029/12005JD005776, 2005.

Hartz, K. E. H., Rosenorn, T., Ferchak, S. R., Raymond, T. M., Bilde, M., Donahue, N. M., and Pandis, S. N.: Cloud condensation nuclei activation of monoterpene and sesquiterpene secondary organic aerosol, J. Geophys. Res., 110, D14208, doi:14210.11029/12004JD005754, 2005.

Havers, N., Burba, P., Lambert, J., and Klockow, D.: Spectroscopic characterization of humic-like substances in airborne particulate matter, J. Atmos. Chem., 29(1), 45-54, 1998.

Heintzenberg, J.: Fine particles in the global troposphere, Tellus Ser. B-Chem. Phys. Meteorol., 41B, 149-160, 1989.

Henning, S., Rosenorn, T., D’ Anna, B., Gola, A. A., Svenningsson, B., and Bilde, M.: Cloud droplet activation and surface tension of mixtures of slightly soluble organics and inorganic salt, Atmos. Chem. Phys., 5, 575-582, 2005, http://www.atmos-chemphys.net/5/575/2005/.

Herckes, P., Lee, T., Trenary, L., Kang, G. G., Chang, H., and Collett, J. L.: Organic matter in Central California radiation fogs, Environ. Sci. Tech., 36(22), 4777-4782, 2002.

Hildemann, L. M., Rogge, W. F., Cass, G. R., Mazurek, M. A., and Simoneit, B. R. T.: Contribution of primary aerosol emissions from vegetation-derived sources to fine particle concentrations in Los Angeles, J. Geophys. Res., 101(D14), 19 541-19549, 1996.

Hoffer, A., Gelencs'er, A., Guyon, P., Kiss, G., Schmid, O., Frank, G., Artaxo, P., and Andreae, M. O.: Optical properties of humiclike substances (HULIS) in biomass-burning aerosols, Atmos. Chem. Phys. Discuss., 5, 7341-7360, 2005, http://www.atmoschem-phys-discuss.net/5/7341/2005/.

Hoffer, A., Kiss, G., Blazso, M., and Gelencser, A.: Chemical characterization of humic-like substances (HULIS) formed from a lignin-type precursor in model cloud water, Geophys. Res. Lett., 31, L06115, doi:06110.01029/02003GL018962, 2004.

IPPC (2001), Intergovernmental Panel on Climate Change (IPCC): Climate Change: The Scientific Basis, Cambridge University Press, UK.

Jacobson, M. C., Hansson, H. C., Noone, K. J., and Charlson, R. J.: Organic atmospheric aerosols: Review and state of the science, Rev. Geophys., 38(2), 267-294, 2000.

Kalberer, M., Paulsen, D., Sax, M., Steinbacher, M., Dommen, J., Prevot, A. S. H., Fisseha, R., Weingartner, E., Frankevich, V., Zenobi, R., and Baltensperger, U.: Identification of polymers as major components of atmospheric organic aerosols, Science, 303(5664), 1659-1662, 2004.

Kanakidou, M., Seinfeld, J. H., Pandis, S. N., et al.: Organic aerosol and global climate modelling: a review, Atmos. Chem. Phys., 5, 1053-1123, 2005, http://www.atmos-chemphys.net/5/1053/2005/.

Kaufman, Y. J., Koren, I., Remer, L. A., Rosenfeld, D., and Rudich, Y.: The effect of smoke, dust, and pollution aerosol on shallow cloud development over the Atlantic Ocean, Proc. Natl. Acad. Sci. USA, 102(32), 11 207-11 212, 2005.

Kiss, G., Tombacz, E., and Hansson, H. C.: Surface tension effects of humic-like substances in the aqueous extract of tropospheric fine aerosol, J. Atmos. Chem., 50(3), 279-294, 2005.
Kiss, G., Tombacz, E., Varga, B., Alsberg, T., and Persson, L.: Estimation of the average molecular weight of humic-like substances isolated from fine atmospheric aerosol, Atmos. Environ., 37(27), 3783-3794, 2003.

Kiss, G., Varga, B., Galambos, I., and Ganszky, I.: Characterization of water-soluble organic matter isolated from atmospheric fine aerosol, J. Geophys. Res., 107, 8339, doi:8310.1029/2001JD000603, 2002.

Koren, I., Kaufman, Y. J., Rosenfeld, D., Remer, L. A., and Rudich, Y.: Aerosol invigoration and restructuring of Atlantic convective clouds, Geophys. Res. Lett., 32, L14828, doi:14810.11029/12005GL023187, 2005.

Kreidenweis, S. M., Koehler, K., DeMott, P. J., Prenni, A. J., Carrico, C., and Ervens, B.: Water activity and activation diameters from hygroscopicity data - Part I: Theory and application to inorganic salts, Atmos. Chem. Phys., 5, 1357-1370, 2005, http://www.atmos-chem-phys.net/5/1357/2005/.

Krivacsy, Z., Gelencser, A., Kiss, G., et al.: Study on the chemical character of water soluble organic compounds in fine atmospheric aerosol at the Jungfraujoch, J. Atmos. Chem., 39(3), 235-259, 2001.

Krivacsy, Z., Kiss, G., Varga, B., et al.: Study of humiclike substances in fog and interstitial aerosol by size-exclusion chromatography and capillary electrophoresis, Atmos. Environ., 34(25), 4273-4281, 2000.

Kumar, P. P., Broekhuizen, K., and Abbatt, J. P. D.: Organic acids as cloud condensation nuclei: Laboratory studies of highly soluble and insoluble species, Atmos. Chem. Phys., 3, 509-520, 2003, http://www.atmos-chem-phys.net/3/509/2003/.

Laaksonen, A., Korhonen, P., Kulmala, M., and Charlson, R. J.: Modification of the Kuhler equation to include soluble trace gases and slightly soluble substances, J. Atm. Sci., 55(5), 853862, 1998.

Lohmann, U. and Feichter, J.: Global indirect aerosol effects: a review, Atmos. Chem. Phys., 5, 715-737, 2005, http://www.atmos-chem-phys.net/5/715/2005/.

Lohmann, U., Feichter, J., Penner, J., and Leaitch, R.: Indirect effect of sulfate and carbonaceous aerosols: A mechanistic treatment, J. Geophys. Res., 105(D10), 12 193-12 206, 2000.

Martin, S. T., Schlenker, J. C., Malinowski, A., Hung, H. M., and Rudich, Y.: Crystallization of atmospheric sulfatenitrate-ammonium particles, Geophys. Res. Lett., 30, 2102, doi:2110.1029/2003GL017930, 2003.

Mayol-Bracero, O. L., Guyon, P., Graham, B., Roberts, G., Andreae, M. O., Decesari, S., Facchini, M. C., Fuzzi, S., and Artaxo, P.: Water-soluble organic compounds in biomass burning aerosols over Amazonia - 2. Apportionment of the chemical composition and importance of the polyacidic fraction, J. Geophys. Res., 107, 8091, doi:8010.1029/2001JD000522, 2002.

McFiggans, G., Artaxo, P., Baltensperger, U., et al.: The effect of physical and chemical aerosol properties on warm cloud droplet activation, Atmos. Chem. Phys. Discuss., 5, 8507-8646, 2005, http://www.atmos-chem-phys-discuss.net/5/8507/2005/.

Mircea, M., Facchini, M. C., Decesari, S., et al.: Importance of the organic aerosol fraction for modeling aerosol hygroscopic growth and activation: a case study in the Amazon Basin, Atmos. Chem. Phys., 5, 3111-3126, 2005, http://www.atmos-chemphys.net/5/3111/2005/.

Mircea, M., Facchini, M. C., Decesari, S., Fuzzi, S., and Charlson, 
R. J.: The influence of the organic aerosol component on CCN supersaturation spectra for different aerosol types, Tellus Ser. BChem. Phys. Meteorol., 54(1), 74-81, 2002.

Nenes, A., Charlson, R. J., Facchini, M. C., Kulmala, M., Laaksonen, A., and Seinfeld, J. H.: Can chemical effects on cloud droplet number rival the first indirect effect?, Geophys. Res. Lett., 29, 1848, doi:1810.1029/2002GL015295, 2002.

Pant, A., Fok, A., Parsons, M. T., Mak, J., and Bertram, A. K.: Deliquescence and crystallization of ammonium sulfate-glutaric acid and sodium chloride-glutaric acid particles, Geophys. Res. Lett., 31, L12111, doi:12110.11029/12004GL020025, 2004.

Peuravuori, J. and Pihlaja, K.: Molecular size distribution and spectroscopic properties of aquatic humic substances, Analytica Chimica Acta, 337(2), 133-149, 1997.

Piccolo, A.: The supramolecular structure of humic substances, Soil Science, 166(11), 810-832, 2001.

Prenni, A. J., De Mott, P. J., and Kreidenweis, S. M.: Water uptake of internally mixed particles containing ammonium sulfate and dicarboxylic acids, Atmos. Environ., 37(30), 4243-4251, 2003.

Pruppacher, H. R. and Klett, J. D.: Microphysics of clouds and precipitation, D. Reidel Publishing Company, Dordrecht, 1980.

Putaud, J. P., Van Dingenen, R., Dell'Acqua, A., Raes, F., Matta, E., Decesari, S., Facchini, M. C., and Fuzzi, S.: Size-segregated aerosol mass closure and chemical composition in Monte Cimone (I) during MINATROC, Atmos. Chem. Phys., 4, 889-902, 2004, http://www.atmos-chem-phys.net/4/889/2004/.

Raymond, T. M. and Pandis, S. N.: Cloud activation of singlecomponent organic aerosol particles, J. Geophys. Res., 107, 4787, doi:4710.1029/2002JD002159, 2002.

Raymond, T. M. and Pandis, S. N.: Formation of cloud droplets by multicomponent organic particles, J. Geophys. Res., 108, 4469, doi:4410.1029/2003JD003503, 2003.

Rissman, T. A., Nenes, A., and Seinfeld, J. H.: Chemical amplification (or dampening) of the Twomey effect: Conditions derived from droplet activation theory, J. Atm. Sci., 61(8), 919930, 2004

Ritchie, J. D. and Perdue, E. M.: Proton-binding study of standard and reference fulvic acids, humic acids, and natural organic matter, Geochim. Cosmochim. Acta, 67(1), 85-96, 2003.

Roberts, G. C., Andreae, M. O., Maenhaut, W., and FernandezJimenez, M. T.: Composition and sources of aerosol in a central African rain forest during the dry season, J. Geophys. Res., 106(D13), 14 423-14 434, 2001.

Rudich, Y.: Laboratory perspectives on the chemical transformations of organic matter in atmospheric particles, Chem. Rev., 103, 5097-5124, 2003.

Samburova, V., Zenobi, R., and Kalberer, M.: Characterization of high molecular weight compounds in urban atmospheric particles, Atmos. Chem. Phys., 5, 2163-2170, 2005, http://www.atmos-chem-phys.net/5/2163/2005/.

Saxena, P., and Hildemann, L. M.: Water-soluble organics in atmospheric particles: A critical review of the literature and application of thermodynamics to identify candidate compounds, J. Atmos. Chem., 24(1), 57-109, 1996.

Schafer, A. I., Mauch, R., Waite, T. D., and Fane, A. G.: Charge effects in the fractionation of natural organics using ultrafiltration, Environ. Sci. Tech., 36(12), 2572-2580, 2002.

Schlenker, J. C., Malinowski, A., Martin, S. T., Hung, H. M., and Rudich, Y.: Crystals formed at $293 \mathrm{~K}$ by aqueous sulfate-nitrate- ammonium-proton aerosol particles, J. Phys. Chem. A, 108(43), 9375-9383, 2004.

Seinfeld, J. H. and Pandis, S. N.: Atmospheric Chemistry and Physics: From Air Pollution to Climate Change, John Wiley, New York, 1998.

Shantz, N. C., Leaitch , W. R., and Caffrey, P. F.: Effect of organics of low solubility on the growth rate of cloud droplets, J. Geophys. Res., 108, 4168, doi:4110.1029/2002JD002540, 2003.

Shulman, M. L., Jacobson, M. C., Carlson, R. J., Synovec, R. E., and Young, T. E.: Dissolution behavior and surface tension effects of organic compounds in nucleating cloud droplets, Geophys. Res. Lett., 23(3), 277-280, 1996.

Simpson, A. J., Kingery, W. L., Spraul, M., Humpfer, E., Dvortsak, P., and Kerssebaum, R.: Separation of structural components in soil organic matter by diffusion ordered spectroscopy, Environ. Sci. Tech., 35(22), 4421-4425, 2001.

Sutton, R., Sposito, G., Diallo, M. S., and Schulten. H. R., Molecular simulation of a model of dissolved organic matter, Environ. Toxicol. Chem., 24(8), 1902-1911, 2005.

Svenningsson, B., Rissler, J., Swietlicki, E., Mircea, M., Bilde, M., Facchini, M. C., Decesari, S., Fuzzi, S., Zhou, J., Mønster, J., and Rosenørn, T.: Hygroscopic growth and critical supersaturations for mixed aerosol particles of inorganic and organic compounds of atmospheric relevance, Atmos. Chem. Phys., 6, 1937-1952, 2006, http://www.atmos-chem-phys.net/6/1937/2006/.

Swift, R. S.: in: Methods of Soil Analysis, Part 3: Chemical Methods. Soil Science Society of America Book Series, edited by: Bigham, J. M. Madison, Wisconsin, Soil Society of America, 1996.

Tagliavini, E., Moretti, F., Decesari, S., Facchini, M. C., Fuzzi, S., and Maenhaut, W.: Functional group analysis by $\mathrm{H}$ NMR/chemical derivatization for the characterization of organic aerosol from the SMOCC field campaign, Atmos. Chem. Phys., 6, 1003-1019, 2006, http://www.atmos-chemphys.net/6/1003/2006/.

Tang, I. N., Fung, K. H., Imre, D. G., and Munkelwitz, H. R.: PhaseTransformation And Metastability Of Hygroscopic Microparticles, Aero. Sci. Tech., 23(3), 443-453, 1995.

Tervahattu, H., Hartonen, K., Kerminen, V. M., Kupiainen, K., Aarnio, P., Koskentalo, T., Tuck, A. F., and Vaida, V.: New evidence of an organic layer on marine aerosols, J. Geophys. Res., 107(D7-D8), 4053, doi:10.1029/2000JD000282, 2002.

Topping, D. O., McFiggans, G. B., and Coe, H.: A curved multicomponent aerosol hygroscopicity model framework: Part 1 - Inorganic compounds, Atmos. Chem. Phys., 5, 1205-1222, 2005, http://www.atmos-chem-phys.net/5/1205/2005/.

Traina, S. J., Novak, J., and Smeck, N. E.: An ultraviolet absorbance method of estimating the percent aromatic carbon content of humic acids, J. Environ. Quality, 19(1), 151-153, 1990.

VanReken, T. M., Ng, N. L., Flagan, R. C., and Seinfeld, J. H.: Cloud condensation nucleus activation properties of biogenic secondary organic aerosol, J. Geophys. Res., 110, D07206, doi:07210.01029/02004JD005465, 2005.

Varga, B., Kiss, G., Ganszky, I., Gelencser, A., and Krivacsy, Z.: Isolation of water-soluble organic matter from atmospheric aerosol, Talanta, 55(3), 561-572, 2001.

Went, F. W.: Blue hazes in the atmosphere, Nature, 187, 641-643, 1960.

Young, K. C. and Warren, A. J.: A reexamination of the derivation 
of the equilibrium supersaturation curve for soluble particles, J. Atm. Sci., 49(13), 1138-1143, 1992.

Zappoli, S., Andracchio, A., Fuzzi, S., et al.: Inorganic, organic and macromolecular components of fine aerosol in different areas of Europe in relation to their water solubility, Atmos. Environ., 33(17), 2733-2743, 1999. 